\title{
Ornamentação do Museu Paulista para o Primeiro Centenário: construção de identidade nacional na década de 1920
}

\author{
Miyoko Makino \\ Museu Paulista da USP
}

Em desenvolvimento a partir de 1990, a primeira fase do projeto de pesquisa sobre a História do Brasil na pintura, privilegiando a pintura histórica como corpus documental, consistiu em englobar obras de diversas instituições, não exclusivamente de museus e de centros culturais. O levantamento inicial mostrou um número relativamente significativo de documentos de interesse, abordando temáticas centradas no descobrimento e na conquista da terra em diferentes regiões e povoamentos; nas fundações de vilas e cidades; nos registros de batalhas e de cenas políticas, considerados relevantes para a História do Brasil; nos eventos relacionados com a Família Real Portuguesa e a Família Imperial do Brasil, bem como nos fatos relativos ao período republicano e nas personalidades reconhecidas por suas atividades em diferentes campos da sociedade.

Na segunda fase do projeto de pesquisa, a presença de parte destas pinturas no Museu Paulista, cerca de oitocentas obras, confeccionadas em óleo e aquarela e sobre diferentes materiais (tela, madeira, metal e papel), justificava um recorte neste núcleo de obras da instituição. Tal núcleo constitui-se de pinturas ${ }^{\top}$ reunidas por iniciativa de Afonso de Escragnolle Taunay, principalmente nas décadas de 20 e 30 do século passado, somadas a outras provenientes de doação de famílias paulistas ou de instituições, feitas por pintores estrangeiros ou nacionais, reconhecidos ou anônimos.

As pinturas encomendadas estão relacionadas com a história paulista do século XVII ao XX; a narrativa iconográfica do movimento das bandeiras; a busca dos índios; a exploração das minas, os caminhos das monções; a exploração agrícola - fazendas de cana e café; vistas da cidade de São Paulo; vistas das vilas paulistas; tipos humanos e costumes paulistas no século XIX; personalidades de destaque para a história paulista - políticos, religiosos,
1. LIMA, S.F. de CARVALHO, V.C. de. "São Paulo antiga, uma encomenda da modernidade: as fotografias de Militão nas pinturas do Museu Paulista". Anais do Museu Paulista. História e cultura Material. Nova série n. 1. São Paulo, 1993. p.147-174. MAKINO, Miyoko. Biografias dos pintores e catalogação das obras citadas (Exposição "São Paulo, uma encomenda da Modernidade"). Anais do Museu Paulista. História e Cultura Material. Nova série n. 1. São Paulo, 1993. p.175-178. MAKINO, Miyoko. Pintura no Museu Paulista. Museu Paulista: Novas Leituras. São Paulo: Museu Paulista da USP, 1995.p.38-57. 
2. TAUNAY, A.de E. Guia da Secção Histórica do Museu Paulista. São Paulo, Imprensa Official do Estado, 1937.

3. ABUD, Kátia Maria. $O$ Sangue Itimorato $e$ as nobilissimas tradições. Tese de Doutorado apresentada ao Departamento de História da Faculdade de Filosofia Letras e Ciências Humana da Universidade de São Paulo. 1985. 242 p. ALVES, Ana Maria de Alencar. Um Museu de Ciências Naturais na História de São Paulo: o Museu do Ipiranga. Dissertação de Mestrado apresentada ao Departamento de História da Faculdade de Filosofia Letras e Ciências Humanas da Universidade de São Paulo. 1998. 209 p. Publicado com o título: $O$ Ipiranga apropriado: ciência, política e poder: o Museu Paulista, 18931922. São Paulo: Humanitas/FFCLH/USP, 2001. ARAÚJO, Karina Anhezini de - Intercâmbios intelectuais e a construção de uma História: Afonso d'Escragnolle Taunay 1911-1929. Dissertação de Mestrado em História. Faculdade de História, Direito e Servico Social da Universidade Estadual Paulista - Campus Franca. Franca, 2003.136 p. BREFE, Ana Cláudia Fonseca. Um lugar de memória para a Nação. O Museu Paulista reinventado por Afonso d'Escragnolle Taunay (1917-1945). Tese de Doutorado apresentada ao Departamento de História do Instituto de Filosofia e Ciências Humanas da Universidade Estadual de Campinas. 1999. 304 p. ELIAS, Maria José. Museu Paulista: Memória e História. Tese de Doutorado apresentada ao Departamento de História da Faculdade de viajantes e literatos, entre outros. A esse conjunto se agregaram as pinturas, principalmente retratos, provenientes de famílias da elite paulista (barões do cafél ou oriundas de demolições de edificações da cidade de São Paulo edifícios públicos, capelas e igrejas. Caso exemplar é a tela Conversão de São Paulo, de José Ferraz de Almeida Júnior.

A variedade das séries temáticas das pinturas encomendadas, algumas já objeto de estudos e publicações, obrigou a limitação não somente do tema como do corpus documental. A terceira fase da pesquisa, portanto, foi marcada por outro recorte: a escolha das pinturas que compõem a ornamentação do Museu para os festejos do Centenário da Independência, projetada por Taunay. Estas pinturas narram episódios da história colonial brasileira, que culminaram na Independência. Destacam-se, no entanto, os retratos, cuja escolha ultrapassou os limites cronológicos, atingindo parte do Segundo Reinado (meados do século XIX). Tal critério explica-se pela atuação marcante dos retratados após o 7 de setembro de 1822, ou seja, na consolidação de nação independente e na construção da identidade nacional. Este aspecto foi retomado por Afonso de E. Taunay ao idealizar a ornamentação do Museu Paulista que, ao contrário do que muitos imaginam, foi elaborado passo a passo na década de 20 e 30 do século passado. Em 1937, quando publicou o Guia da Secção Histórica do Museu Paulista², dava por concluída a sua história do Brasil ilustrada, embora ainda faltassem duas pinturas que chegaram ao Museu em 1962 e 1963.

Estas imagens atualmente são muito requeridas por editoras, empresas e pesquisadores com objetivos diferenciados, desde a publicação de livros de arte, didáticos, paradidáticos ou empresariais até trabalhos acadêmicos, em diferentes níveis, ou edição de documentários de curta e longa metragem e CD-roms. Utilizadas de forma descontextualizada do conjunto alegórico e simbólico do qual fazem parte para então se tornarem ilustrações do passado, a apropriação editorial de muitas dessas imagens faz com que disseminem-se como verdades históricas em um circuito de consumo ainda maior do que o Museu poderia alcançar. A pesquisa ampla, nesta terceira fase, atingiu parcialmente seu objetivo, detendo-se mais na descrição do que na análise da demanda atual por imagens do passado.

Otema já foi explorado por outros trabalhos acadêmicos, tais como os que surgiram nas duas últimas décadas a respeito do Museu Paulista, de Afonso de Taunay e dos Bandeirantes. Destacam-se, entre outros, os estudos realizados por Kátia Maria Abud, Paulo Cavalcante de Oliveira Júnior, Eduardo Victorio Morettin, Maria Margaret Lopes, Ana Maria Alencar; Cecília Helena de Salles Oliveira, José da Costa Oliveira Filho, Maria José Elias, Ana Cláudia Fonseca Brefe, José Sebastião Witter (Org.) e Karine Anhezini de Araújo ${ }^{3}$.

Apesar do volume considerável de estudos existentes, alguns aspectos do processo em causa não foram devidamente explorados, mas são observáveis nos relatórios anuais de Taunay: a decoração começou a ser pensada em 1919 mas não havia um projeto claro, que só se delinearia no decorrer de duas décadas; uma história que começou atendendo aos anseios da sociedade paulista da época, mas que acabou por se transformar em história nacional; não se tratou de síntese de história colonial, mas de uma história que ultrapassou esse limite, inserindo-se no cenário político do Segundo Reinado, pelo menos até 1860, cuja preocupação principal para 1922 era a preparação do Salão de Honra.

Para a pesquisa proposta, a identificação dos diferentes níveis da narrativa histórica da Nação foi complementada com as fontes impressas. $\bigcirc$ uso 


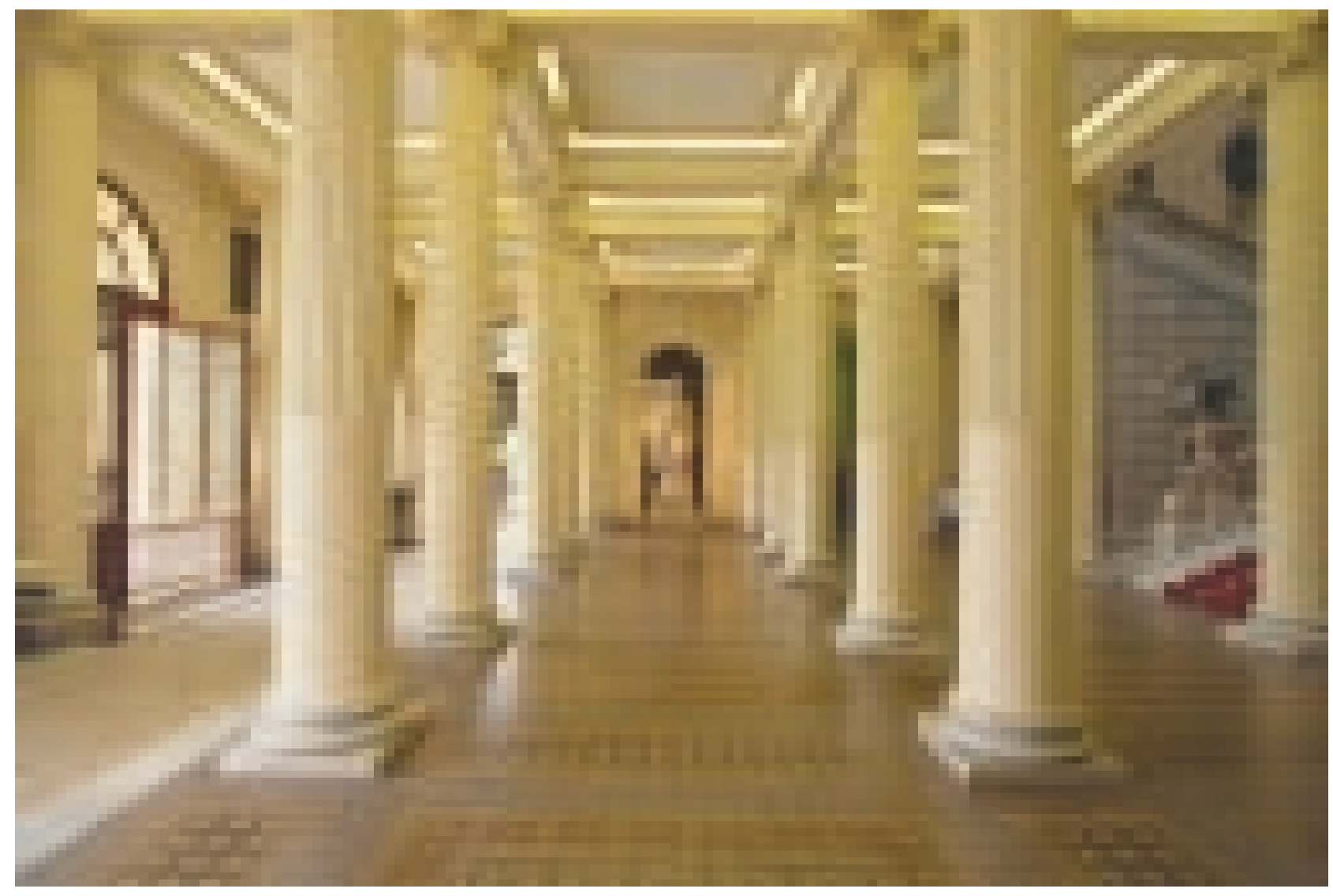

FIGURA 1 - Vista do Saguão - colunas e, ao fundo, escultura do bandeirante Antonio Raposo Tavares, de Luigi Brizzollara. Fotografia de José Rosael. Acervo do Museu Paulista da USP. 


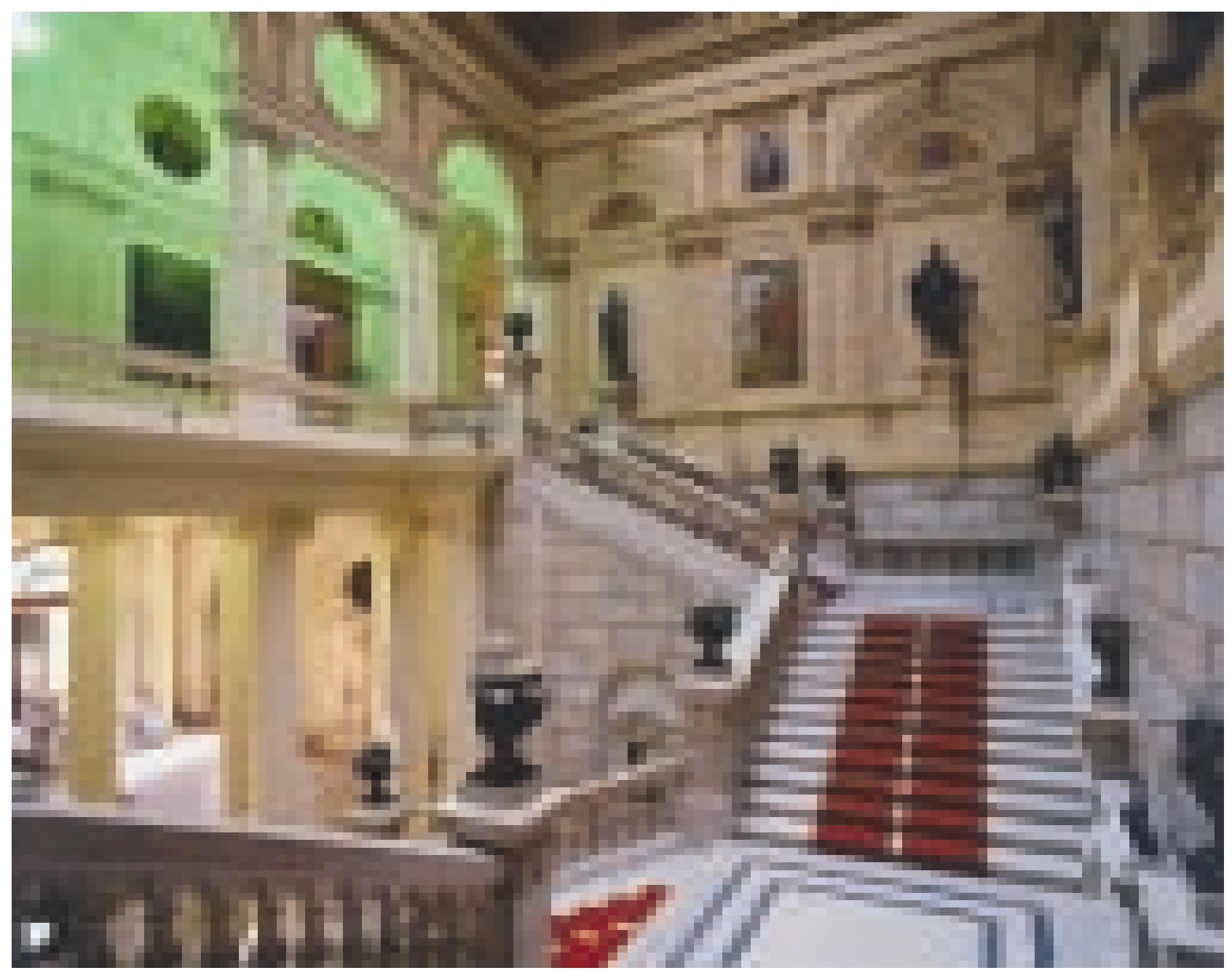

FIGURA 2 - Vista parcial do Saguão com a escultura de Antonio Raposo Tavares. Escadaria, $2^{\circ}$ lanço, 2 patamares, 9 ânforas, nas pilastras e junto às paredes, com águas dos rios. Lateral Leste: esculturas de Francisco Dias Velho e Manoel de Borba Gato, de autoria de Nicola Rollo; Brasões de Taubaté e Porto Feliz; Posse da Amazônia, de J. Fernandes Machado; retrato de Domingos José Martins, de Oscar Pereira da Silva. Lateral norte parcial e Galeria frontal. Fotografia de Hélio Nobre. Acervo do Museu Paulista da USP. 


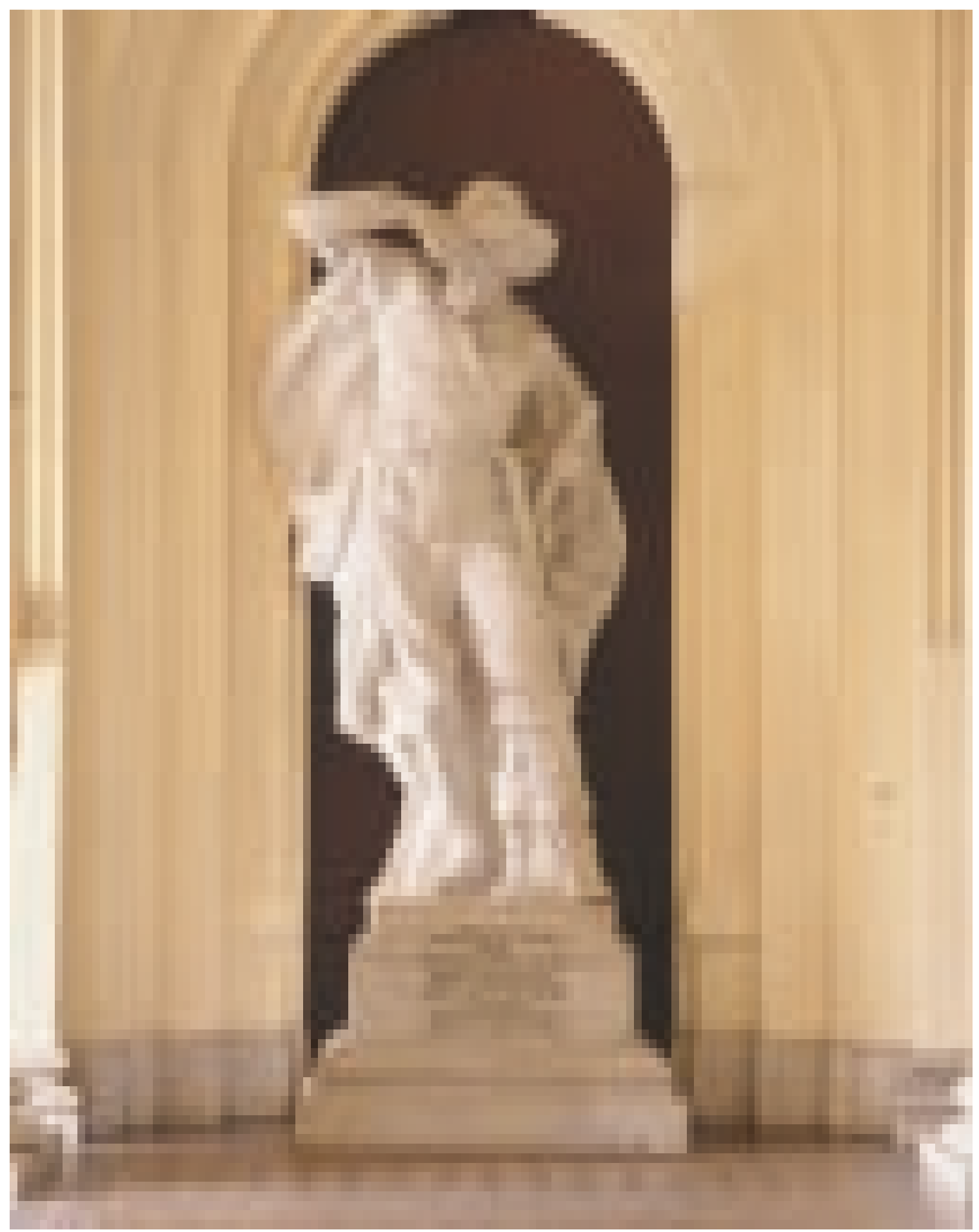

FIGURA 3 - Escultura de Antonio Raposo Tavares, autoria de Luigi Brizzolara, c. 1920. Fotografia de José Rosael. Acervo do Museu Paulista da USP. 
Filosofia, Letras e Ciências Humanas da Universidade de São Paulo. 1996. 2 vols. $1^{\circ}$ vol. 317 p. Anexos. LOPES, Maria Margaret. As ciências naturais e os museus no Brasil no século XIX. Tese de Doutorado apresentada ao Departamento de História da Faculdade de Filosofia Letras e Ciências Humanas da Universidade de São Paulo,1993; publicada com o título: $O$ Brasil descobre a pesquisa científica: os museus e as ciências naturais no século XIX. São Paulo: Hucitec, 1997. MORETTIN, Eduardo Victorio - Cinema e História: uma análise do filme "Os Bandeirantes". Dissertação de Mestrado apresentada ao Departamento de Cinema, Rádio e Televisão da Escola de Comunicações e Artes da Universidade de São Paulo. 1995.285 p. OLIVEIRA, Cecília Helena de Salles. O "Espetáculo do Ypiranga": Mediações entre história e memória. Tese apresentada à Divisão de Acervo e Curadoria do Museu Paulista da Universidade de São Paulo para Concurso de Livre Docência. 2000. 288 p. OLIVEIRA FILHO, José da Costa. O edifício do $\mathrm{Mu}$ seu Paulista: um pouco da história do edifício Monumento de Bezzi. Dissertação de Mestrado apresentada ao Departamento de História da Faculdade de Filosofia, Letras e Ciências Humanas da Universidade de São Paulo. 2000. 2 vols. OLIVEIRA JR., Paulo Cavalcante. Affonso d'E. Taunay e a construção da memória bandeirante. Dissertação de Mestrado apresentada ao Departamento de História do Instituto de Filosofia e Ciências Sociais da Universidade Federal do Rio de Janeiro. 1994. 204 p. WITTER, José Sebastião de relatórios e outros documentos afins ${ }^{4}$, publicações como Vultos da Independência de Afonso de Escragnolle Taunay (1922) e outras obras comemorativas ${ }^{5}$ foi constante, tendo como objetivo a releitura do desenvolvimento do plano de ornamentação apresentado por Taunay ao governo do Estado de São Paulo.

A área prevista para as comemorações do Centenário compreendia o Saguão, a Escadaria, o Salão de Honra e quatro salas do primeiro andar (B-7, B8, B-9 e B-1 0). É interessante notar a seqüência apresentada, que no decorrer de seu encaminhamento acabou por se concentrar apenas em uma área - o Salão de Honra.

O objetivo era "fazer a evocação de todos os grandes lances da História do Brasil revestindo o edifício do Museu de uma feição de pantheon, empolgadora ao primeiro contacto da vista dos visitantes com as suas pinturas e esculpturas ${ }^{6 \prime}$.

A partir dos relatórios foi possível verificar que o projeto inicial sofreu alterações, motivadas seja pelo espaço físico e fontes originais disponíveis, seja pelos recursos alocados para esse fim. Taunay, engenheiro dado a estudos históricos e proveniente de família de artistas, soube identificar e apropriar para seu projeto os espaços e pedestais deixados pelo arquiteto Tommaso Gaudenzio Bezzi no Saguão, na Escadaria bifurcada e em três lanços compreendidos entre as paredes norte, sul, leste e oeste do edifício, incluindo a área que circunda a clarabóia, estendendo-se à galeria em frente ao Salão de Honra e a este propriamente dito.

É conveniente salientar que, às vésperas dos festejos, queixando-se da insuficiência de verba para o Museu, Taunay frisou a necessidade de complementarse a decoração do Saguão com mais duas estátuas e quatro painéis, sintetizando o século XVI paulista, em preparação ao bandeirismo, com a apresentação das figuras de Martim Afonso de Sousa, José de Anchieta, Brás Cubas, cacique Tibiriçá, D. Francisco de Sousa e Afonso Sardinha. A preocupação de Taunay se estendeu também à ocupação das duas loggias laterais da escadaria, que seriam ocupadas pelas placas de bronze com os nomes dos que se envolveram com as lutas pela Independência ou colaboraram para a sua consolidação. Enumerando as medidas tomadas para a conservação do edifício, externa e internamente, além do mobiliário expositivo e de guarda de acervo, lembrou-se Taunay dos pormenores, despesas necessárias para acompanhar à altura a decoração que se empreendia ${ }^{7}$.

No Saguão, a fim de ocupar quatro painéis e oito locais para retratos, a concepção original homenageou as "primeiras manifestações de independência do espírito nacional" - cena da Inconfidência Mineira, Guerra dos Emboabas, Guerra dos Mascates e Rebelião Mineira de 1720. Quanto aos retratos, pensouse nos envolvidos nos citados episódios. No entanto, estas idéias vingaram parcialmente. No Saguão ficaram duas esculturas em mármore medindo cada uma delas três metros de altura incluindo o pedestal, feitas por Luigi Brizzolara, estatuário italiano de renome. As duas estátuas, no dizer de Taunay, resumiriam as fases do bandeirantismo: Antônio Raposo Tavares, o ciclo da busca da mãode-obra indígena, seja no sertão, seja nos aldeamentos jesuíticos; e a devassa e exploração do distante sertão. A mão alçada à fronte simboliza o gesto do conquistador de terras, a extensão alcançada pela sua expedição, a exploração do horizonte.

Fernão Dias Paes Leme simboliza a fase seguinte, aquela do descobrimento do ouro e de pedras preciosas, inaugurando-se o chamado "ciclo do ouro", com o povoamento do sertão. O gesto simbólico representado na escultura é o da cabeça inclinada, olhar voltado para um pedaço de mineral que traz na mão. 
Para Taunay, a verba concedida foi insuficiente para decorar o Saguão, que sintetizaria "o século XVI paulista, de preparação ao surto das bandeiras". Planejava colocar mais duas estátuas, João Ramalho e Tibiriçá, "patriarchas europeu e americano da gente de S. Paulo"8. Isto não foi possível, e encomendou em seu lugar quatro painéis a José Wasth Rodrigues, retratando em 3/4, D. João III, aquele que iniciou a colonização, e Martim Afonso de Sousa, que comandou a expedição colonizadora em 1530 e fundou a primeira vila brasileira, São Vicente. Taunay não iniciou seu projeto com o descobrimento do Brasil, mas com a colonização, tendo como ponto de partida a presença de europeus, antes mesmo do movimento colonizador: João Ramalho e filho e Tibiriçá e Neto, retratados alegoricamente de corpo inteiro. Estes painéis são posteriores a 1922, em 1934 colocou-se o painel com a figura simbólica de Tibiriçáa.

Em 1926 Taunay pensou em adicionar os brasões de cidades paulistas, em ordem cronológica de fundação, fora da escadaria, preenchendo os semicírculos deixados na parede frontal do Museu. Na galeria oeste, no andar térreo, encontrou espaço para mais seis escudos representando, segundo ele, as cidades maiores do Brasil 10 .

Outra preocupação de Taunay dirigiu-se para a ornamentação da Escadaria, sem que houvesse um projeto global. As idéias foram sendo delineadas entre 1919 e 1922, sendo que alguns aspectos permaneceram, outros foram substituídos após contribuições de historiadores e artistas.

$\mathrm{Na}$ Escadaria, reconheceu Taunay como engenheiro, as intenções arquitetônicas do entorno - um nicho grande para estátua e seis consolos ou pedestais para estátuas menores, e acima, na frisa, quatro medalhões, dois na parede sul e um em cada lateral; nove espaços semicirculares e dois retangulares, para "ahi collocar 24 effigies...", dispondo duas em cada área semicircular para evitar "a continuidade da linha figura sobre figura" 1 .

A escolha dos retratados recaiu sobre os "vultos da Independência", abrangendo "precursores, propagandistas, principaes actores, os martyres de idéa etc." 12

Para a concretização do projeto de decoração, Taunay solicitou a colaboração de dois artistas: Rodolfo Bernardelli para a ornamentação da escadaria, e Rodolfo Amoedo para o projeto da Sanca, ambos residentes no Rio de Janeiro. A Adrien-Henri-Vital Van Emelen coube a concepção das esculturas dos bandeirantes e dos suportes de bronze das ânforas de vidro, estes feitos para conter as águas dos rios brasileiros, representando cada um deles um ou mais Estados brasileiros.

A representação da Nação no Museu Paulista, através das águas dos rios, foi a estratégia adotada para a inserção de elementos alegóricos na construção da identidade nacional, aos quais somaram-se também exemplares da fauna (especialmente aves) e da flora.

nicho foi projetado para conter a escultura de D. Pedro I, solicitada a Rodolfo Bernardelli pela Comissão de Construção do Monumento do Ipiranga em 1890, entregue somente em 1923, e inaugurada no dia 7 de setembro do mesmo ano.

Para o Centenário, Taunay recorreu à Escola Nacional de Belas Artes para empréstimo temporário, por parte do diretor João Batista da Costa e do ministro do Interior, Fernando Chaves, do busto de bronze de D. Pedro I, feito por Marcos Ferrez, logo após o 7 de setembro de 1822, com ornatos heráldicos. (dir.). Museu Paulista: Um Monumento no Ipiranga (História de um edifício centenário e de sua recuperação). Direção-geral José Sebastião Witter; organização Heloisa Barbuy. São Paulo: Federação e Centro das Indústrias do Estado de São Paulo, 1997.

4. Relatórios do Museu Paulista de 1922, 1923, 1925, 1926, 1927, 1928, 1929, 1930, 1934, 1936, 1937 - datilografados. Relatório especial $n^{\circ} 4$ sobre os trabalhos do exassistente João Alberto José Robbe, na antiga Secção de História Nacional. 1948. Datilografado. Revista do Museu Paulista, tomo X, 1918 Relatório de 1917.Revista do Museu Paulista, tomo XI, 1919 - Relatório de 1918. Revista do Museu Paulista, tomo XII, 1920 Relatório de 1919. Revista do Museu Paulista, tomo XIII, 1923 - Relatório de 1920. Revista do Museu Paulista, tomo XIV, 1926 - Relatórios de 1921, 1922 e 1923. Inventário Avulso de 1925, com anotações e acréscimos feitos por Afonso de Escragnolle Taunay. Inventários de Coleções de História do Museu Paulista. Inventário de Telas - 1957.

5. TAUNAY, Afonso de E. Grandes Vultos da Independência Brasileira. Publicação comemorativa do Primeiro Centenário da Independência Nacional. São Paulo: Melhoramento, 1922. 229 p. TAUNAY, Afonso de E. Guia da Secção Histórica do Museu Paulista. São Paulo: Imprensa Oficial do Estado, 1937. TAUNAY, Afonso de E. Commemoração do Cincoentenário do Museu Paulista no Palácio do Ipiranga. São Paulo: Imprensa Oficial do Estado, 1946. 52 p. 


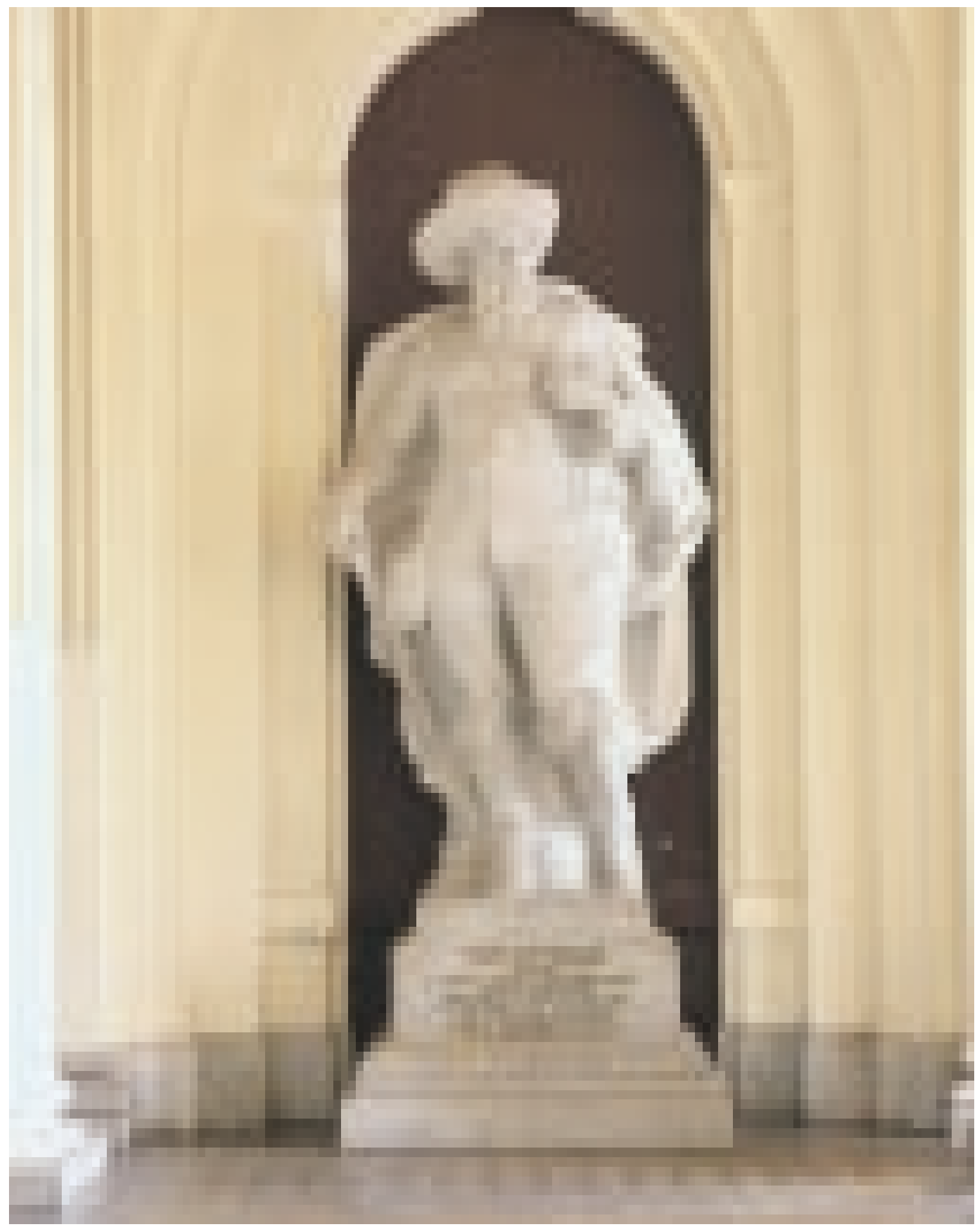

FIGURA 4 - Escultura de Fernão Dias Paes Leme, de autoria de Luigi Brizzolara.c. 1920. Fotografia de José Rosael. Acervo do Museu Paulista da USP. 


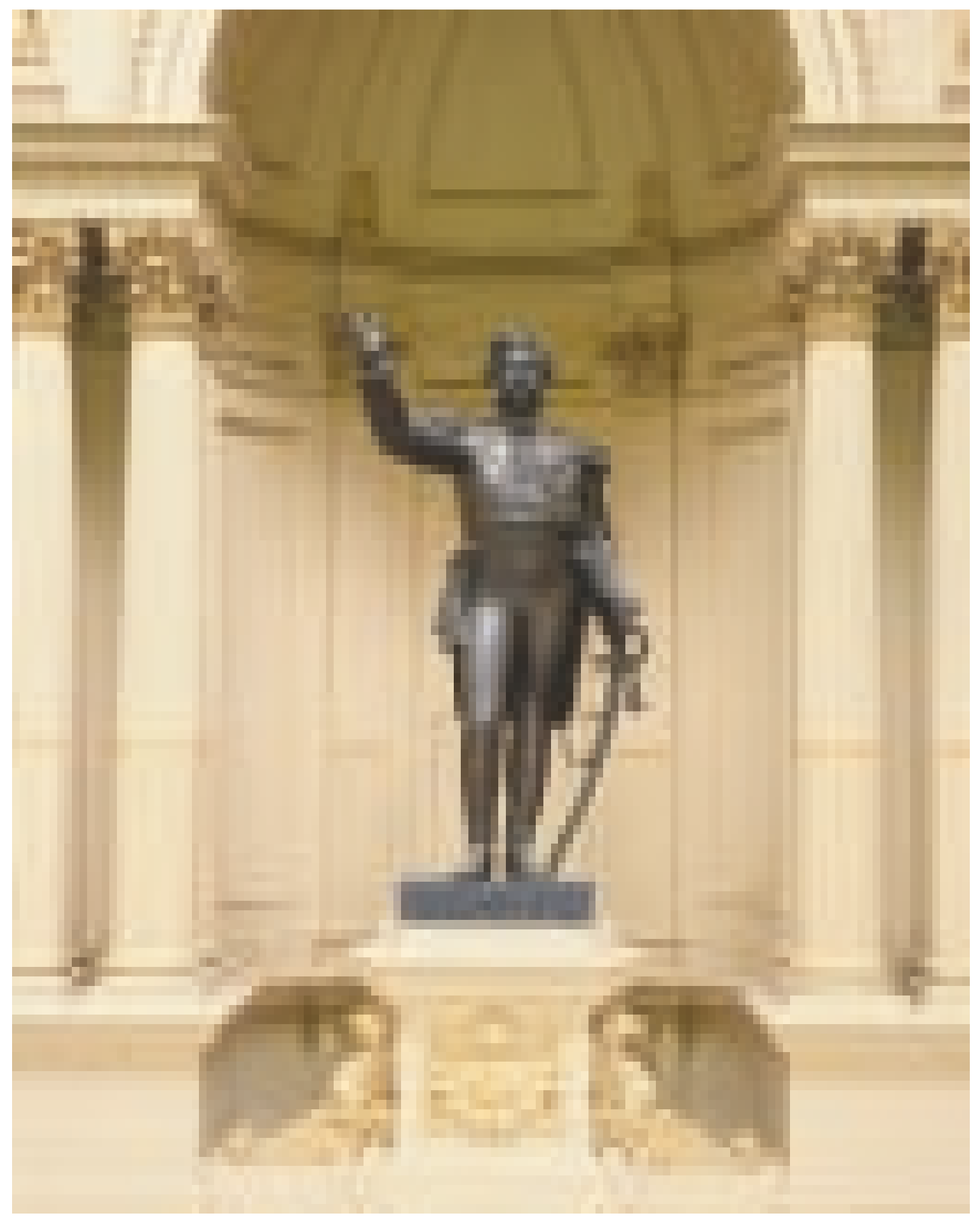

FIGURA 5 - Nicho central: pedestal, ladeado pelos dragões, medalhão PI, Escultura de D. Pedro I, de autoria de Rodolfo Bernardelli. Fotografia de José Rosael. Acervo do Museu Paulista da USP. 
6. Taunay, Affonso d'Escragnolle. Relatório referente ao anno de 1919 apresentado, a 28 de fevereiro de 1920, ao Excellentissimo Senhor Secretario do Interior, Doutor Oscar Rodrigues Alves, pelo Director, em Commissão, do Museu Paulista. Separata/44 p. Revista do Museu Paulista, tomo XI, 1919.p.37.

7. Taunay, A. d'E. Relatório referente ao anno de 1921... p. 11.

8. Taunay, Affonso d'Escragnolle. Relatório referente ao anno de 1922 ... p. 60.

9. Relatório referente ao anno de 1934 , apresentado, a 28 de janeiro de 1935, ao Snr. Dr Marcio P. Munhoz, dignissimo Secretario d'Estado dos Negocios da Educação e da Saúde Pública, pelo Director do Museu Paulista, Affonso d'Escragnolle Taunay. Datilografado.p. 29

10. Relatório referente ao anno de 1926 ... p. 34.

11. Taunay, A.d' E. Relatório referente ao anno de 1919...p.38.

12. Taunay, A.d'E. Relatório referente ao anno de 1919 ...p.38.
Duas de um conjunto de seis esculturas foram encomendadas respectivamente a Amadeo Zani, Nicola Rollo e Van Emelen.

Outras estátuas anteriormente cogitadas para a escadaria, encostadas à parede em pedestais menores, recordariam Filipe dos Santos, Manuel Beckman e os participantes da Revolução Pernambucana de 1817 (Domingos José Martins, Domingos Teotônio Jorge, padre Roma e outros). Prevaleceram, no entanto, as esculturas dos seis bandeirantes em bronze, que ladeiam o nicho. Obedeceu-se ao projeto de Van Emelen, que recebeu elogios de pareceristas chamados por Taunay, Mario Whateley e Bruno Magro. A escolha privilegiou figuras importantes e simbólicas do bandeirismo de São Paulo: Francisco de Brito Peixoto (Rio Grande do Sul-1738); Manoel Preto (Paraná-1 853); Manoel de Borba Gato (Minas Gerais1720); Paschoal Moreira Cabral (Mato Grosso-1748); Bartolomeu Bueno da Silva, o Anhangüera (Goiás-1744); Francisco Dias Velho (Santa Catarina-1738). Em cada pedestal assinalou-se o nome do Estado alcançado pelo bandeirante e a data de sua separação do território de São Paulo. As esculturas ressaltam a indumentária do bandeirante que ficou no imaginário popular - o chapéu com abas largas, botas de canos altos, bacamartes, polvarinho e facão. Duas esculturas apresentam o gibão de armas ou "aramas de algodão", o "esculpil dos hespanhóes", no dizer de Taunay.

O projeto de Amoedo, na sanca, previu dezoito retratos dos "próceres" da Independência e, nos quatro cantos, medalhões em baixo-relevo com molduras de ramos de louro e carvalho, tendo no centro quatro datas significativas para os movimentos de libertação do Brasil: 1720 (Filipe dos Santos), 1789 (Inconfidência Mineira), 1817 (Revolução Pernambucana) e 1822 (Independência).

Os serviços de pintura dos retratos e de escultura dos medalhões com as datas comemorativas foram entregues a Oscar Pereira da Silva e a Domenico Failutti, que se comprometeram a entregá-los com molduras até fins de março de 1922. No ano seguinte, os pintores conseguiram entregar a metade do número de retratos encomendados: Lino Coutinho, Cipriano Barata, Hipólito da Costa, frei Sampaio, Vergueiro e Curado (lateral sul); Labatut, Sóror Angélica e Lima e Silva (lateral oeste). Completaram posteriormente com os retratos de Pirajá, Cochrane, Paula e Souza (lateral leste) e Rebouças, Maricá, Barbacena, Valença, Queluz e Cairu (lateral norte).

Taunay recorreu a famílias, arquivos, bibliotecas e museus para conseguir as imagens que serviram de modelo para os retratos a óleo. Alguns líderes não puderam ser representados por não terem-se obtido referências fisionômicas, mas foram recordados em duas placas de bronze que se encontram nas laterais da Escadaria Central, no Saguão.

Em 1919, Taunay havia planejado a colocação de sete painéis com temas relativos aos acontecimentos ocorridos em torno de 7 de setembro de 1822. Refez, entretanto, seu pensamento, alterando a temática da representação para "um episódio da repulsa ao estrangeiro", desde o século $\mathrm{XVI}$. A referência diz respeito às invasões francesas, holandesas e espanholas: lo) "Estácio de Sá e expulsão dos franceses do Rio de Janeiro em 1567"; 2ㅇ) "D. Marcos Teixeira e os holandeses na Bahia, em 1624"; 3의 "Jerônimo de Albuquerque Maranhão e franceses do Maranhão"; 4ㅇ "Matias de Albuquerque e primeira fase contra os holandeses"; 5) "João Fernandes Vieira, André Vidal de Negreiros, Henrique Camarão e a expulsão dos holandeses"; 6ㅇ) "A viagem de Pedro Teixeira pela Amazônia até Tabatinga" 


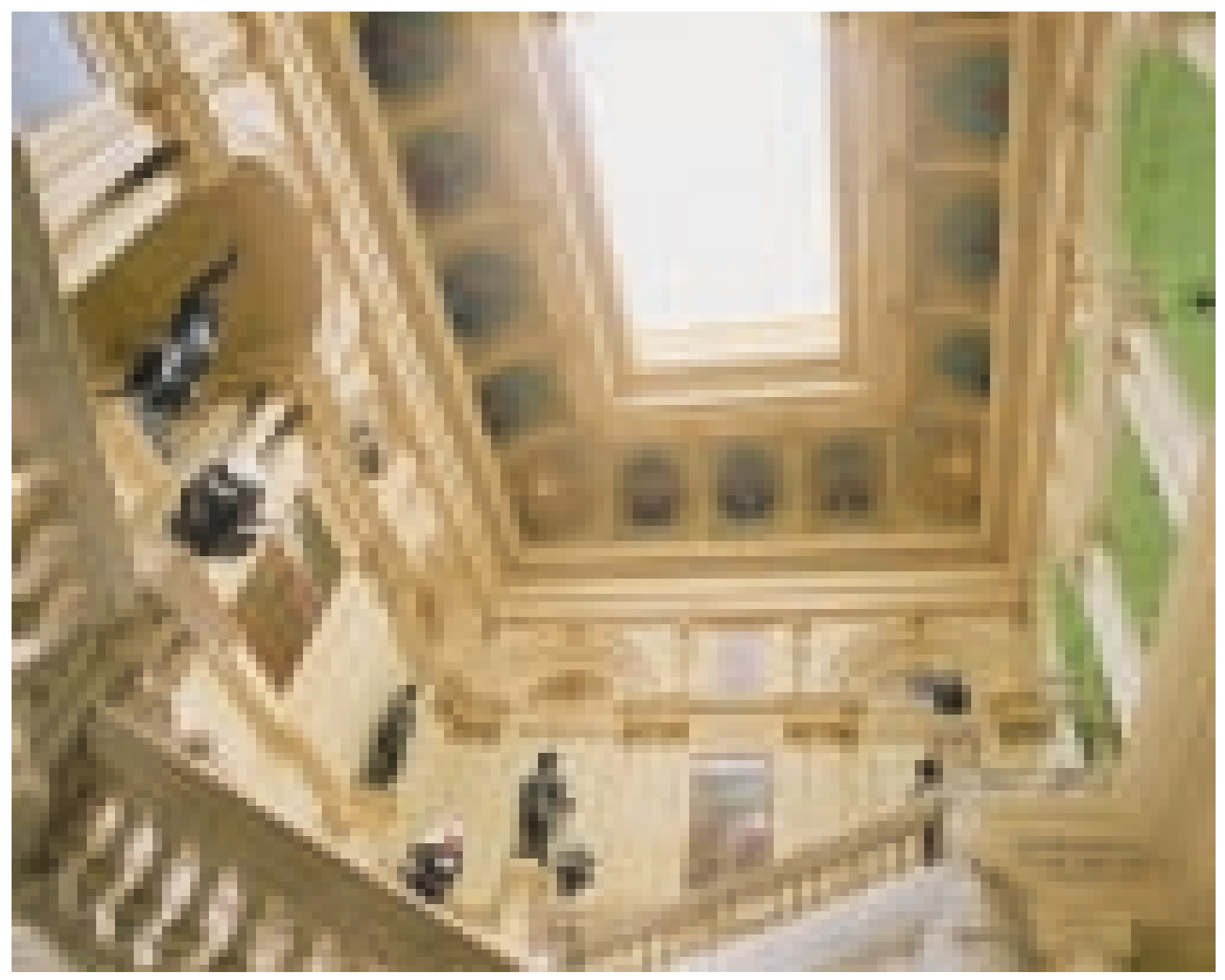

FIGURA 6 - Vista parcial da Sanca (10 retratos), nicho com escultura de D. Pedro I, painéis ciclo do gado e ciclo do ouro, brasões(ltu e Itanhaem), esculturas de bandeirantes e ânforas com águas dos rios (lateral sul - 4, lateral oeste -3 e lateral norte parcial -3 ), Tiradentes, Medalhões 1720, 1822. Fotografia de José Rosael. Acervo do Museu Paulista da USP. 


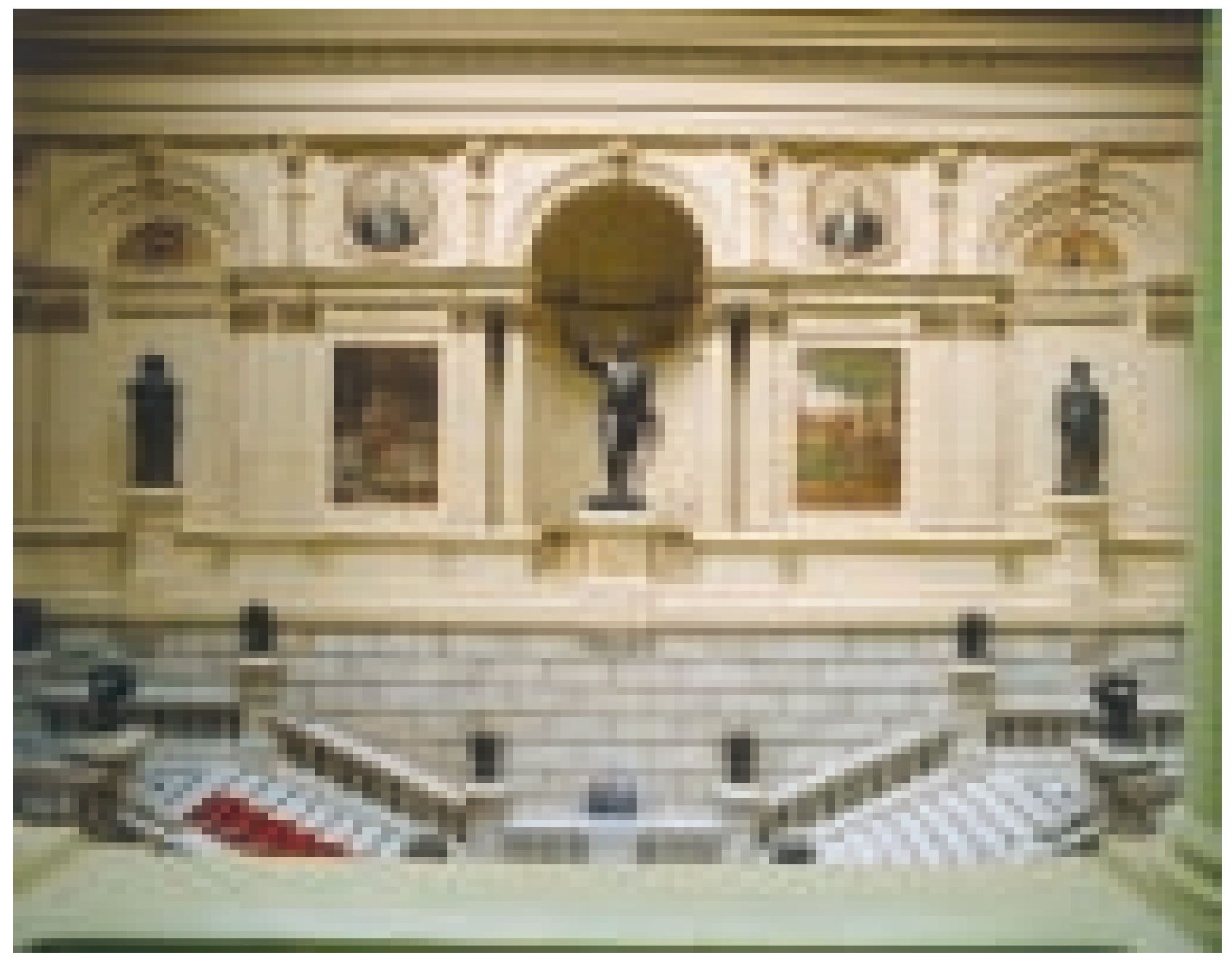

FIGURA 7 - Vista parcial da escadaria (esquerda, direita) ânforas (9); Bandeirantes (Bartolomeu Bueno da Silva e Pascoal Moreira Cabrall Painéis ciclos Caça ao índio e Creadores de Gado; Brasões (Parnaíba e Sorocaba); irmãos Andradas; Nicho central. Fotografia de José Rosael. Acervo do Museu Paulista da USP. 
e 7의 "Episódio das guerras do extremo sul para a fixação das fronteiras" 13. Esta idéia, porém, não se concretizou.

Posteriormente, foram propostos outros temas relativos a cenas de bandeirismo que, reformulados, passaram a representar os ciclos econômicos: Posse da Amazônia (U.Fernandes Machado, 1924); Ciclo da Caça ao Índio (Henrique Bernardelli, 1924); Creadores de Gado (João Batista da Costa, 1924) e Ciclo do Ouro (Rodolfo Amoedo, 1924); para um episódio da expulsão dos holandeses, A Retirada do Cabo de São Roque Henrique Bernardelli, entregue em 1927); e para dois atos administrativos referentes à mineração: Extração do Ouro, 1700 e Provedor das Minas, 1700 (ambos de Joaquim da Rocha Ferreira), que ficaram prontos em 1962 e 1963. Observando-se as datas - 1924, 1927 1962 e 1963 - percebe-se que esta parte não estava pronta nos festejos do Centenário. A ornamentação completou-se mais de quarenta anos depois dos festejos do Primeiro Centenário.

A preocupação de Taunay com a decoração prendeu-se à complementação da decoração com oito vasos de bronze e nove pequenos painéis em arco, acima das estátuas de bronze de bandeirantes. Nesses nove painéis, abandonando a idéia de neles se colocar retratos, Taunay resolveu encomendar os escudos (brasões) das mais antigas cidades do Estado de São Paulo, marcadas pela tradição bandeirante: São Paulo, Santos, São Vicente, Itu, Sorocaba, Taubaté, Parnaiba, Porto Feliz e Itanhaem ${ }^{14}$.

Estes nove brasões foram encomendados em 1925 a José Wasth Rodrigues, que recebeu a encomenda no ano seguinte. Os serviços foram pagos pelo Automóvel Club de São Paulo, que colaborou com cinco contos de réis, e pelo Club Comercial de São Paulo, com dois contos de réis. A intermediação junto às diretorias das instituições foi realizada por Henrique de Souza Queiroz, com a concordância de Paulo Prado e de Joaquim Pinto Pereira de Almeida ${ }^{15}$.

Os brasões expostos no início de 1926, como previsto, receberam nota no jornal Correio Paulistano, que os classificou como "centros primordiaes e principaes de bandeirantismo", tal o espírito que dominava na época ${ }^{16}$. Os brasões de Santos, São Paulo e São Vicente foram fixados no alto da parede da galeria, próximo do Salão de Honra, intercalados pelos retratos de Januário da Cunha Barbosa e de José Joaquim da Rocha, que fazem frente aos retratos de Martim Francisco e Antônio Carlos (lateral sul). $\bigcirc$ auxílio das prefeituras e câmaras municipa is foi importante para completar a exposição dos brasões, com a inclusão dos nomes das cidades, datas da fundação e os nomes dos fundadores, em letras em alto relevo ${ }^{17}$.

Taunay, por outro lado, tinha a intenção de pôr nas ânforas de vidro as águas coletadas in loco nos rios. Os suportes de bronze trariam as características de fauna e flora da região, no caso das bacias amazônica e platina; para a bacia do Prata, a anhuma, e para a amazônica, o jacamim. Nas pilastras da escadaria, oito vasos ${ }^{18}$. Nas oito pilastras menores previu-se colocar vasos também menores.

Em 1928, conseguiu Taunay expor os vasos com as águas dos rios nas pilastras da escadaria. Taunay obteve as águas tanto de particulares quanto de governos de Estado, que recordou e enumerou em seu relatório. Nos lados, ficaram duas pilastras com suportes de bronze e ânforas de cristal contendo águas misturadas dos rios dos extremos do Brasil: de um lado, Oiapoque e Chuí (norte-sul) e, de outro, Javari e Capibaribe (leste e oeste). Completou-se em
13. Taunay, A.d' E. Relatório referente ao anno de $1919 \ldots$... 38 e 39.

14. Relatório referente ao anno de 1924 , apresentado, a 15 de janeiro de 1925 , ao Excelentissimo Senhor Secretario do Interior, Doutor José Manoel Lobo, pelo Director do Museu Paulista, Affonso d'Escragnolle Taunay. Datilografado.p. 12 .

15. Esta foi a segunda vez em que Henrique de Souza Queiroz contribuiu para o Museu Paulista, sensibilizando a sociedade. Relatório referente ao anno de 1925 , apresentado, a 28 de janeiro de 1926, ao Excelentissimo Senhor Secretario do Interior, Doutor José Manoel Lobo, pelo Director do Museu Paulista, Affonso d'Escragnolle Taunay. Datilografado.p.23.

16. Relatório referente ao anno de 1926, apresentado, a 28 de janeiro de 1927, ao Excelentissimo Senhor Secretario do Interior, Doutor José Manoel Lobo, pelo Director do Museu Paulista, Affonso d'Escragnolle Taunay. Datilografado.p. 33 .

17. Relatório referente ao anno de 1926 ... p. 34.

18. Relatório referente ao anno de 1927 , apresentado, janeiro de 1928 , ao Excelentissimo Senhor Secretario do Interior, Doutor Fábio de Sá Barreto, pelo Director do Museu Paulista, Affonso d'Escragnolle Taunay. Datilografado.p.18. 


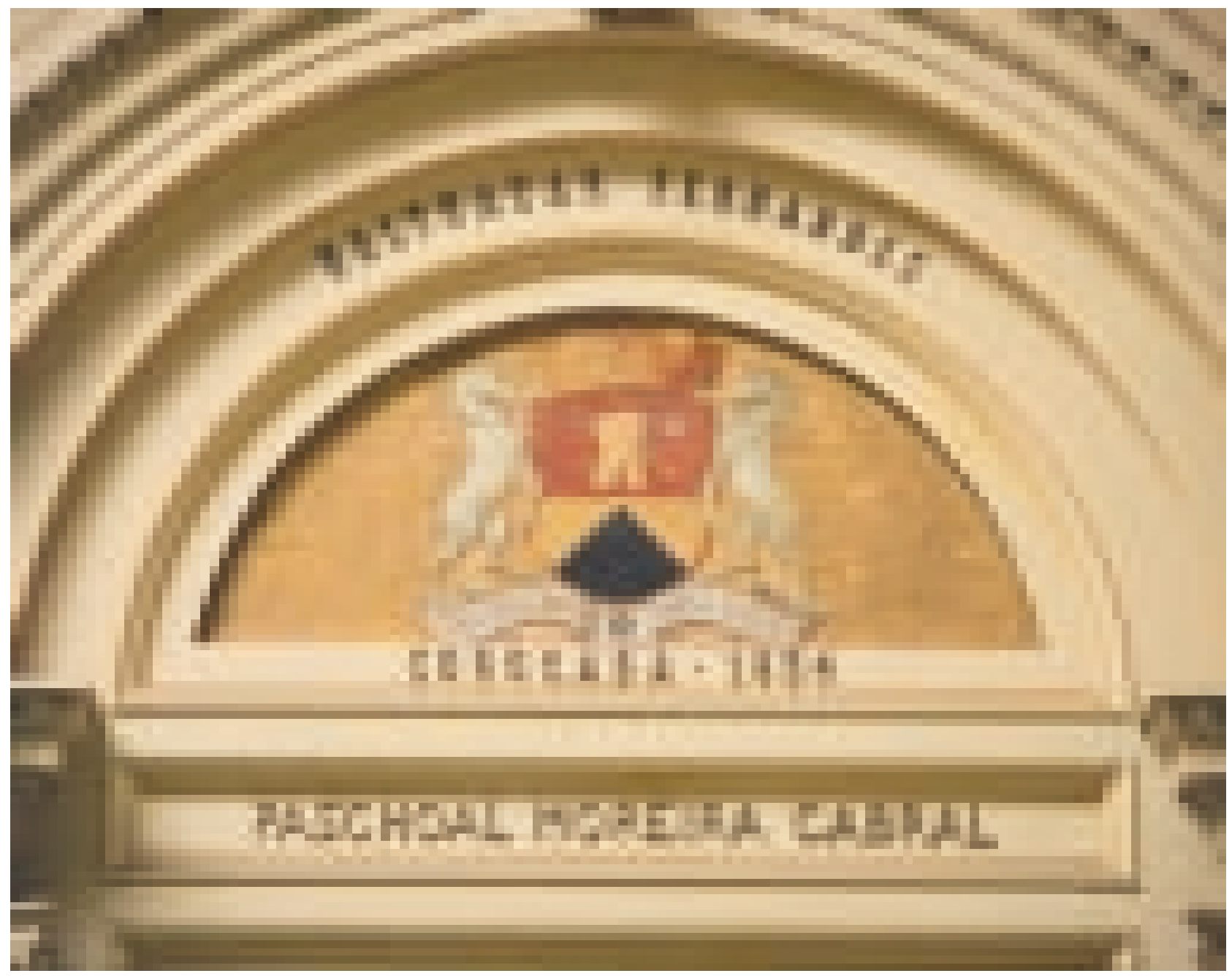

FIGURA 8 - Brasão de Sorocaba, integral, fundador (Balthazar Fernandes) e ano de fundação 1654. Fotografia de Hélio Nobre. Acervo do Museu Paulista da USP. 


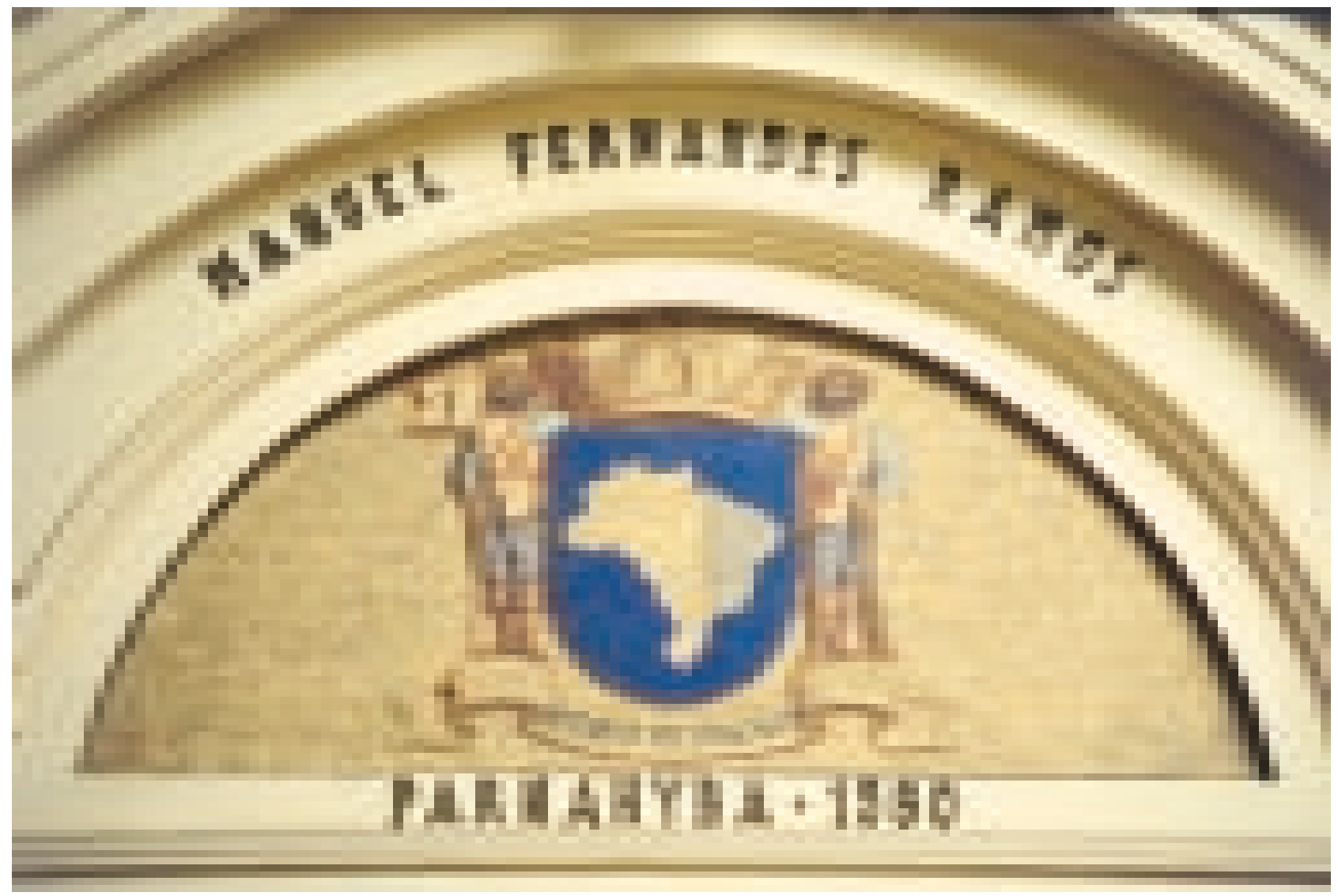

FIGURA 9 - Brasão de Parnaíba, integral, Manuel Fernandes Ramos, Parnahyba, 1580. Fotografia de Hélio Nobre. Acervo do Museu Paulista da USP. 


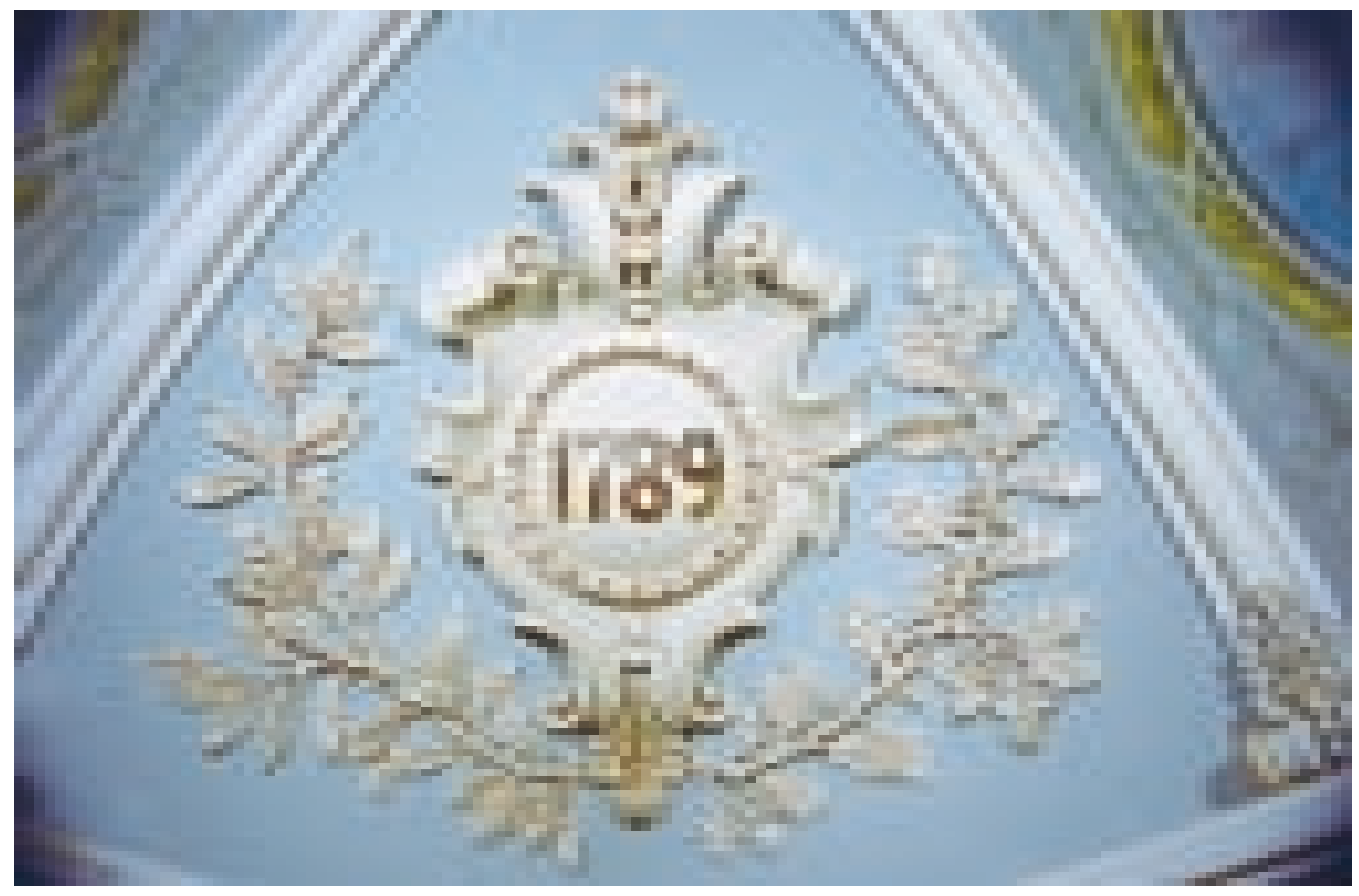
da USP. 


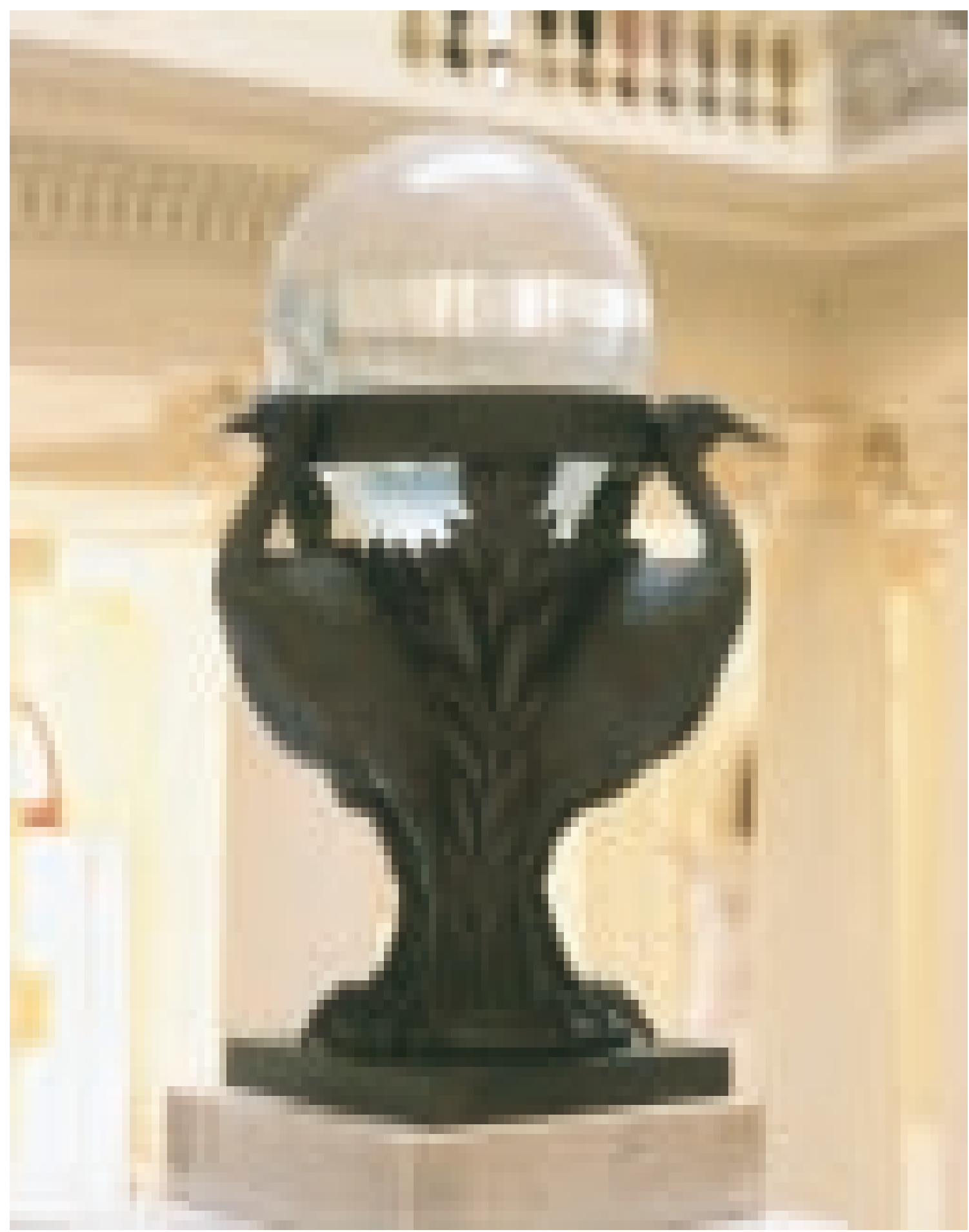

FIGURA 11 - Ânfora no pedestal da escadaria, sem identificação. Fotografia de Hélio Nobre. Acervo do Museu Paulista da USP. 


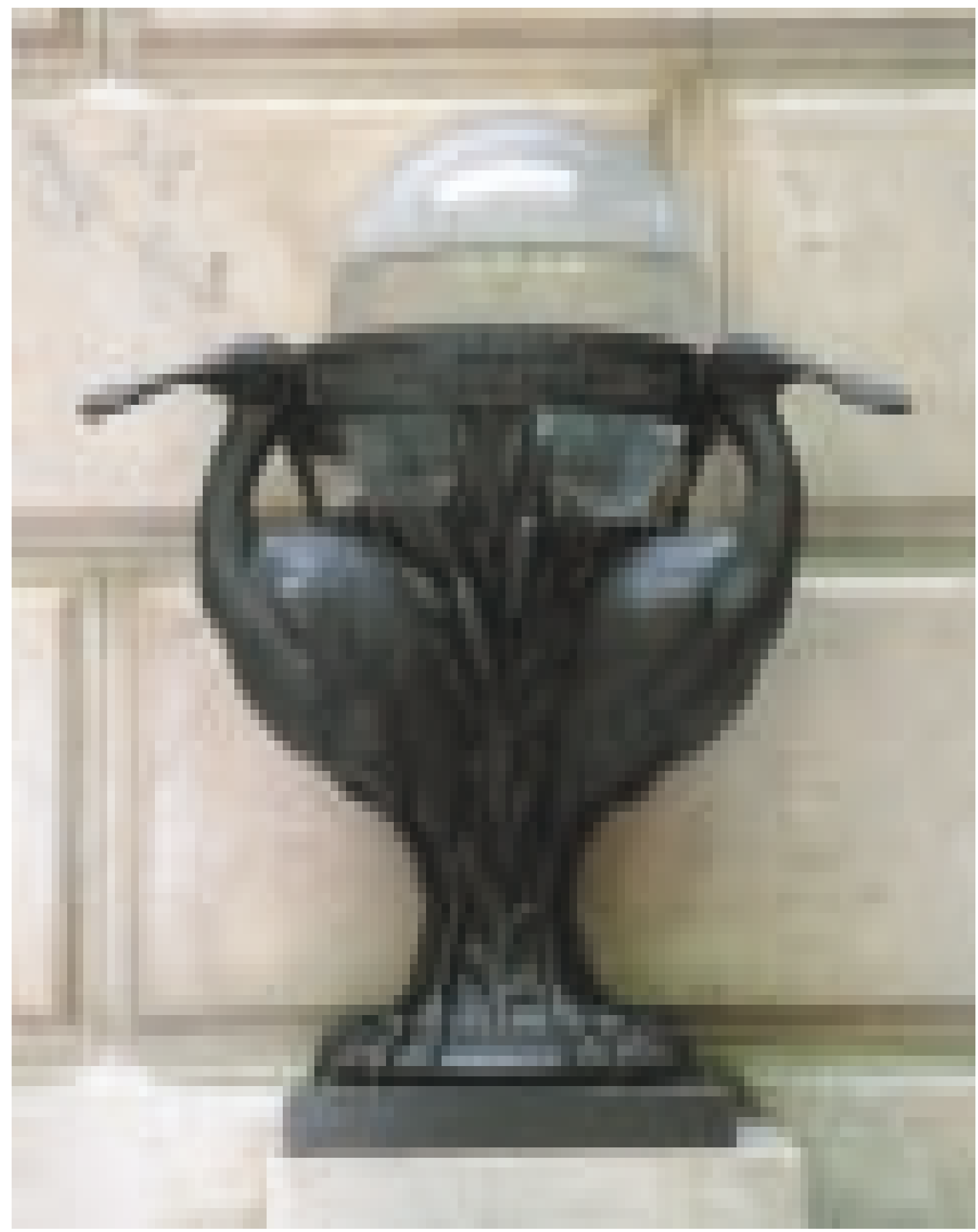

FIGURA 12 - Ânfora rios Leste-Oeste, extremos do Brasil, Javary-Capiberibe. Fotografia de Hélio Nobre. Acervo do Museu Paulista da USP. 
1930 a colocação dos vasos com as águas dos rios: 16 ânforas ao todo. Os rios foram: Amazonas, Javari, Purus, Parnaíba, Jaguaribe, Doce, Paraíba, Assu (das Piranhas), Jaguaribe, Doce, Paraíba, Oiapoque, Chuí, Javari, Capibaribe e Carioca ${ }^{19}$.

Os suportes de bronze foram fundidos nas casas de Curcio Zanio e Metello Benedetti e Paperetti. A preocupação inicial e prioritária de Taunay foi o Salão de Honra, local onde se encontrava a pintura histórica de Pedro Américo de Figueiredo e Melo (1843-1905), "Independência ou Morte", encomenda feita pela Comissão de Construção do Monumento, em fins de 1885, deixando o arquiteto Tommaso Gaudenzio Bezzi espaço para a fixação do quadro. A pintura, realizada em Florença, Itália, em 1888, esteve exposta nesse local e nos Estados Unidos. Foi trazida ao Brasil e colocada no edifício em 1894 e aberta à visitação pública em 7 de setembro de 1895.

Taunay, para complementar a decoração do Salão, planejou a mostra de cinco retratos (nos nichos redondos) e quatro painéis que relatassem episódios mais próximos relacionados ao 7 de setembro. Buscou retratos de D. Pedro I (1798 - 1834), José Clemente Pereira (1787-1854), Diogo Antônio Feiió (1784-1843), José Bonifácio de Andrada e Silva (1763-1838) e Joaquim Gonçalves Ledo (178 1-1847), encomendados a Oscar Pereira da Silva (1 867 1939). O importante a destacar é a questão do retrato de Ledo, cuja pesquisa se estendeu até os Estados Unidos, tendo sido os esforços infrutíferos para encontrá-lo. Com o Salão ornamentado, inclusive com as molduras em alto relevo, com o símbolo da Casa de Bragança, os Dragões e o medalhão Pl, em 1921, por ordem do presidente de Estado, completou-se a decoração com o retrato de Ledo.

Considerando os episódios ocorridos no Primeiro Reinado e na Regência entre os políticos retratados, muito mais adversários do que correligionários, Taunay posicionou-os lado a lado, destacando a unanimidade e a concordância necessárias para a construção da identidade nacional, por meio da Independência. O outro ponto estratégico, tendo em vista o plano de urbanização em torno do "sítio histórico", foi a centralidade do retrato de D. Pedro I, acima do quadro de Pedro Américo e a direção para o horizonte, a Avenida D. Pedro I, prevista em fins da década de 20 do século passado, pelo então prefeito de São Paulo, Washington Luís de Sousa.

Nos outros dois quadros, Taunay, conforme suas palavras, resolveu homenagear duas figuras femininas: D. Leopoldina de Habsburgo (1797-1826) e seus filhos e Maria Quitéria de Jesus Medeiros (1752 1853), entregando a factura dos painéis ao comendador Domenico Failluti (ltália?), que esteve em São Paulo, nas primeiras décadas do século XX, pintando e expondo seus quadros. Para Taunay foi importante destacar a atuação de D. Leopoldina no processo de emancipação política, na consolidação da monarquia e na sua continuidade, com o futuro D. Pedro II e a continuidade também em outro continente, com D. Maria da Glória, a D. Maria II de Portugal. Quanto a Maria Quitéria, Taunay recuperou a narrativa de Maria Grahan e mostrou a atuação das tropas brasileiras na Bahia, expulsando os portugueses. Salientou, com esta homenagem, a figura de D.Pedro I, que condecorou a heroína baiana.

Aos retratos somaram-se os dois painéis históricos, em lugar dos quatro previstos: o Príncipe D. Pedro e Jorge de Avilez a bordo da Fragata União e Sessão das Corte de Lisboa, ambos de autoria de Oscar Pereira da Silva.
19. Relatório referente ao anno de 1930 , apresentado, em 26 de janeiro de 1931, ao Excelentissimo Senhor Secretario do Interior, Doutor Fábio de Sá Barreto, pelo Director do Museu Paulista, Affonso d'Escragnolle Taunay. Datilografado. p.19. 


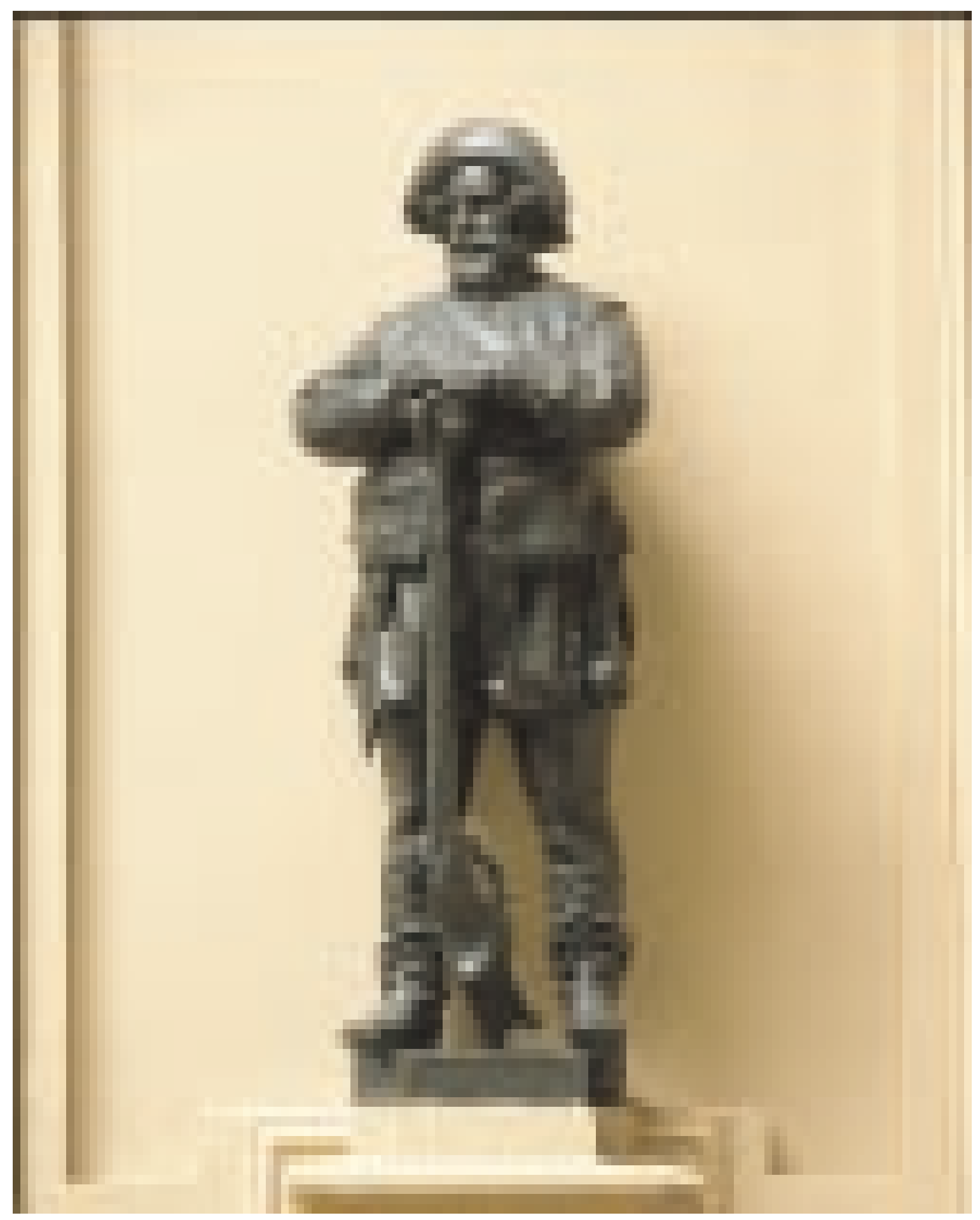

FIGURA 13 - Escultura de Bartolomeu Bueno da Silva - Anhanguera. Fotografia de Hélio Nobre. Acervo do Museu Paulista da USP. 


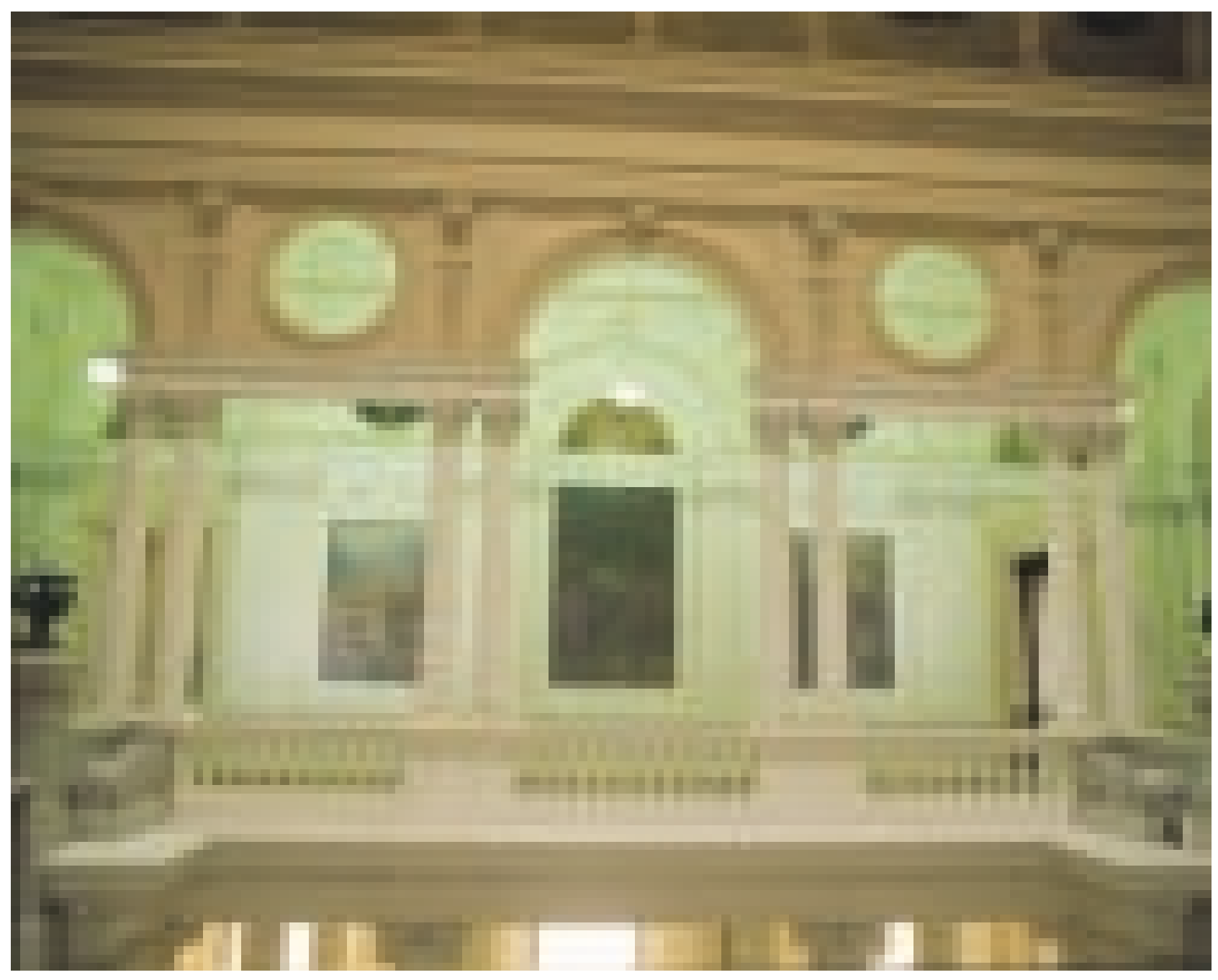

FIGURA 14 - Galeria em frente ao Salão de Honra - Lateral Norte - colunas, arcos, óculos, Painéis Extração do Ouro, 1700 - Retirada do Cabo de São Roque, Brasão de São Paulo, Provedor das Minas, 1700, de Joaquim da Rocha Ferreira. Fotografia de José Rosael. Acervo do Museu Paulista da USP. 


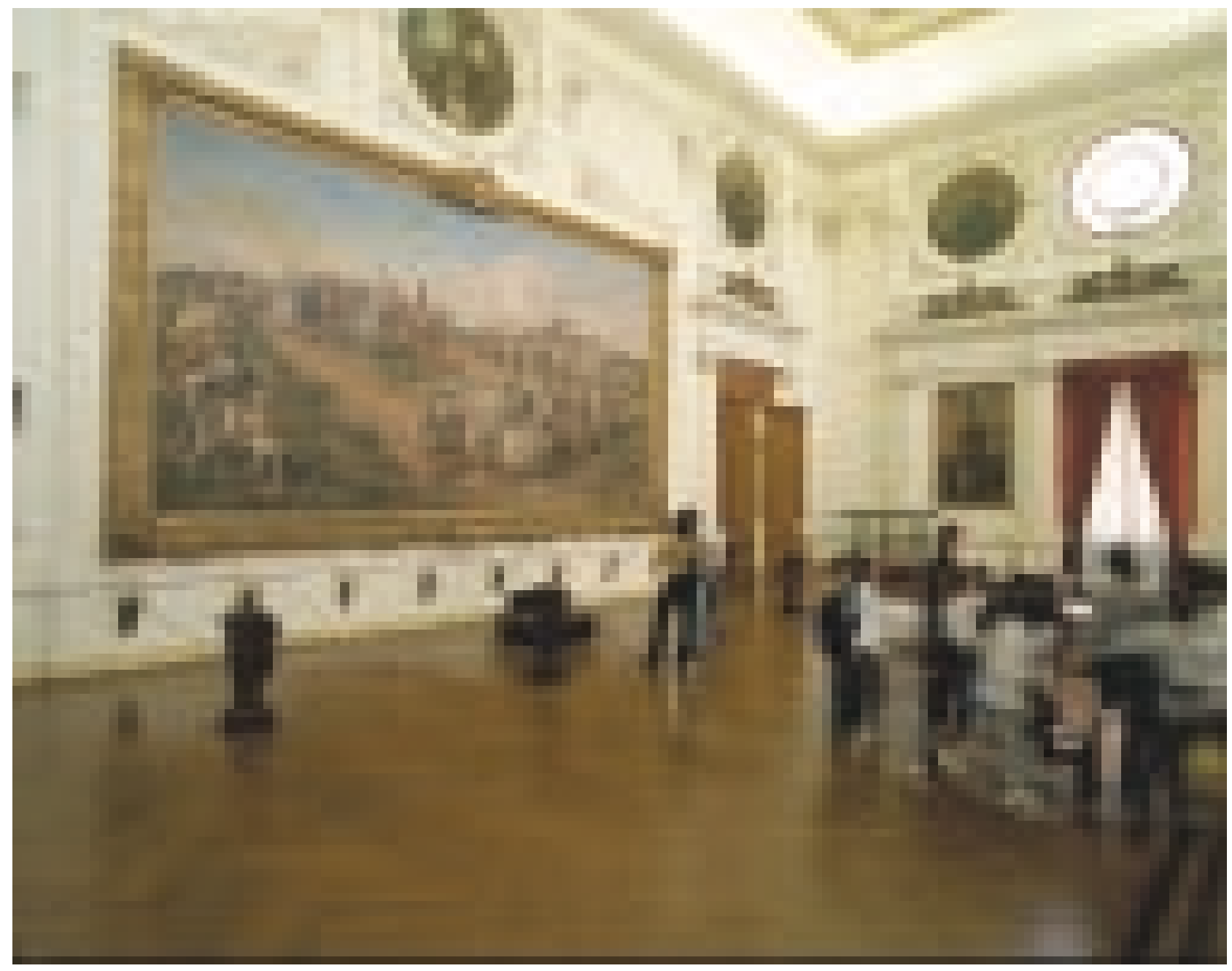

FIGURA 15 - Vista parcial do Salão de Honra (lado oeste) - Independência ou Morte e Maria José Rosael. Acervo do Museu Paulista da USP. 


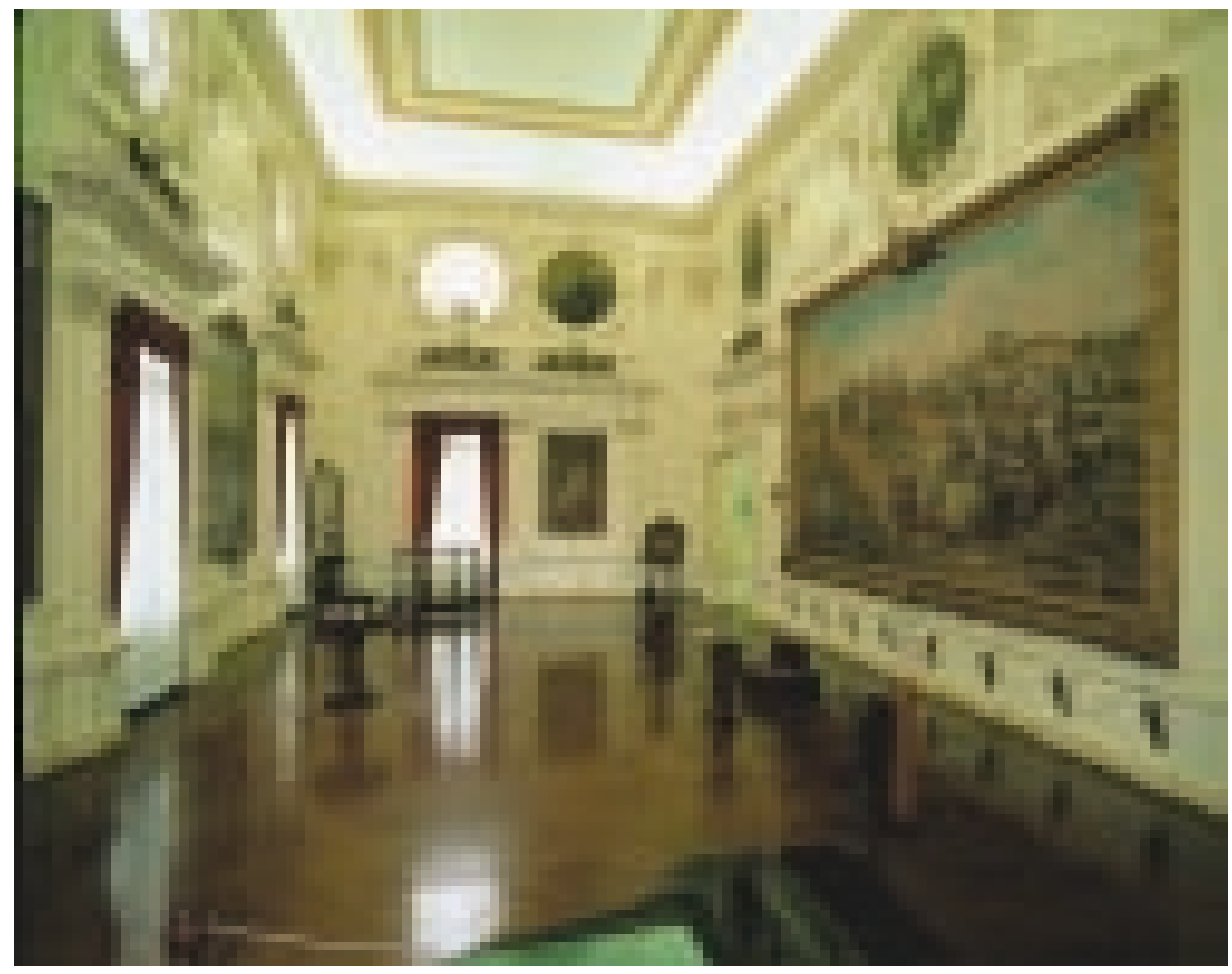

FIGURA 16 - Vista parcial do Salão de Honra (lado leste) Independência ou Morte, de Pedro Américo e Maria Leopoldina. Retratos nos óculos D. Pedro I, José Bonifácio de Andrada e Silva e Joaquim Gonçalves Ledo. Fotografia de José Rosael. Acervo do Museu Paulista da USP. 


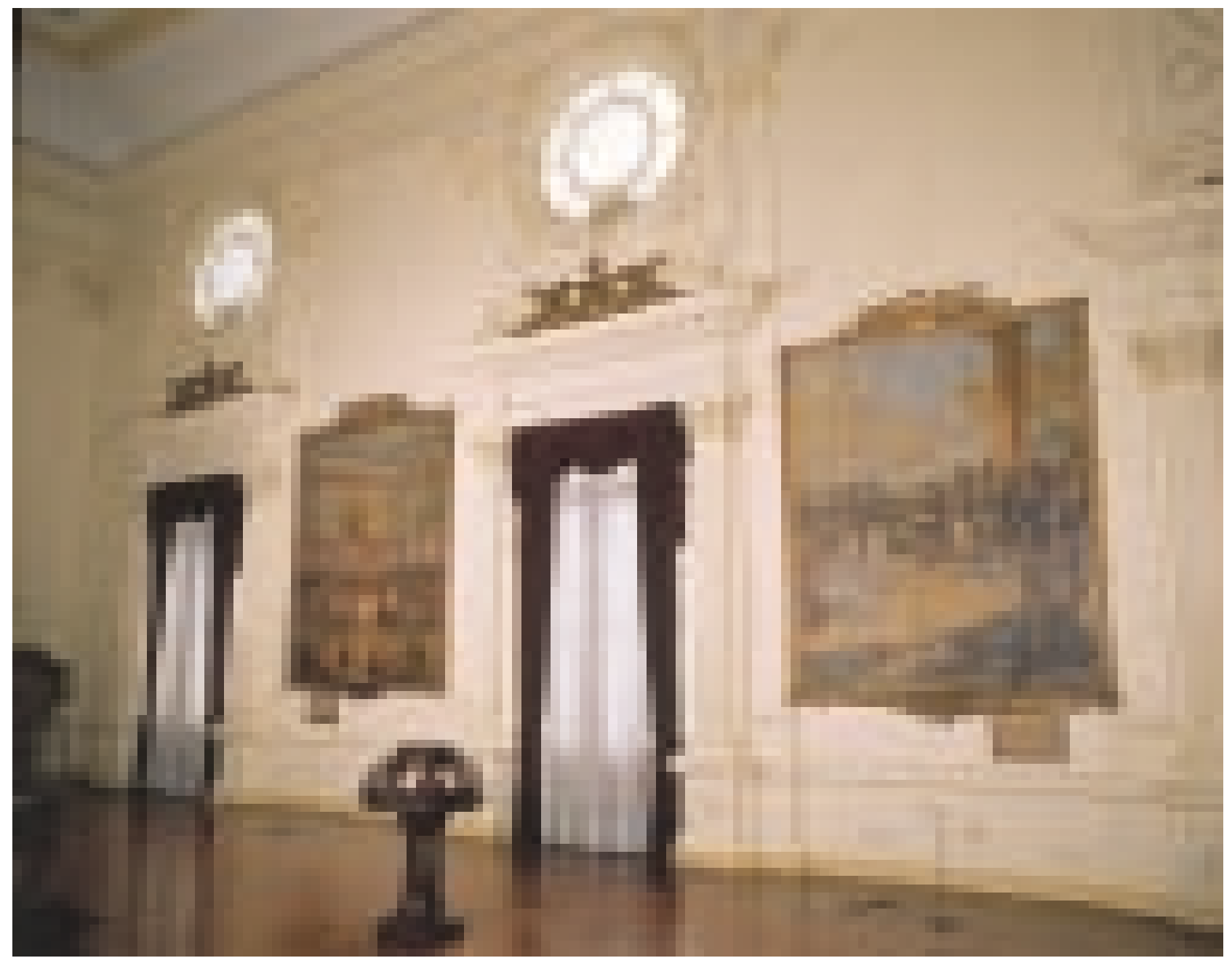

FIGURA 17 - Vista parcial do Salão de Honra: ornamentação em baixo-relevo, dragões, medalhão Pl e os painéis históricos Sessão das Cortes de Lisboa e Príncipe D. Pedro e Jorge Avilez a bordo da Fragata União. Fotografia de José Rosael. Acervo do Museu Paulista da USP. 


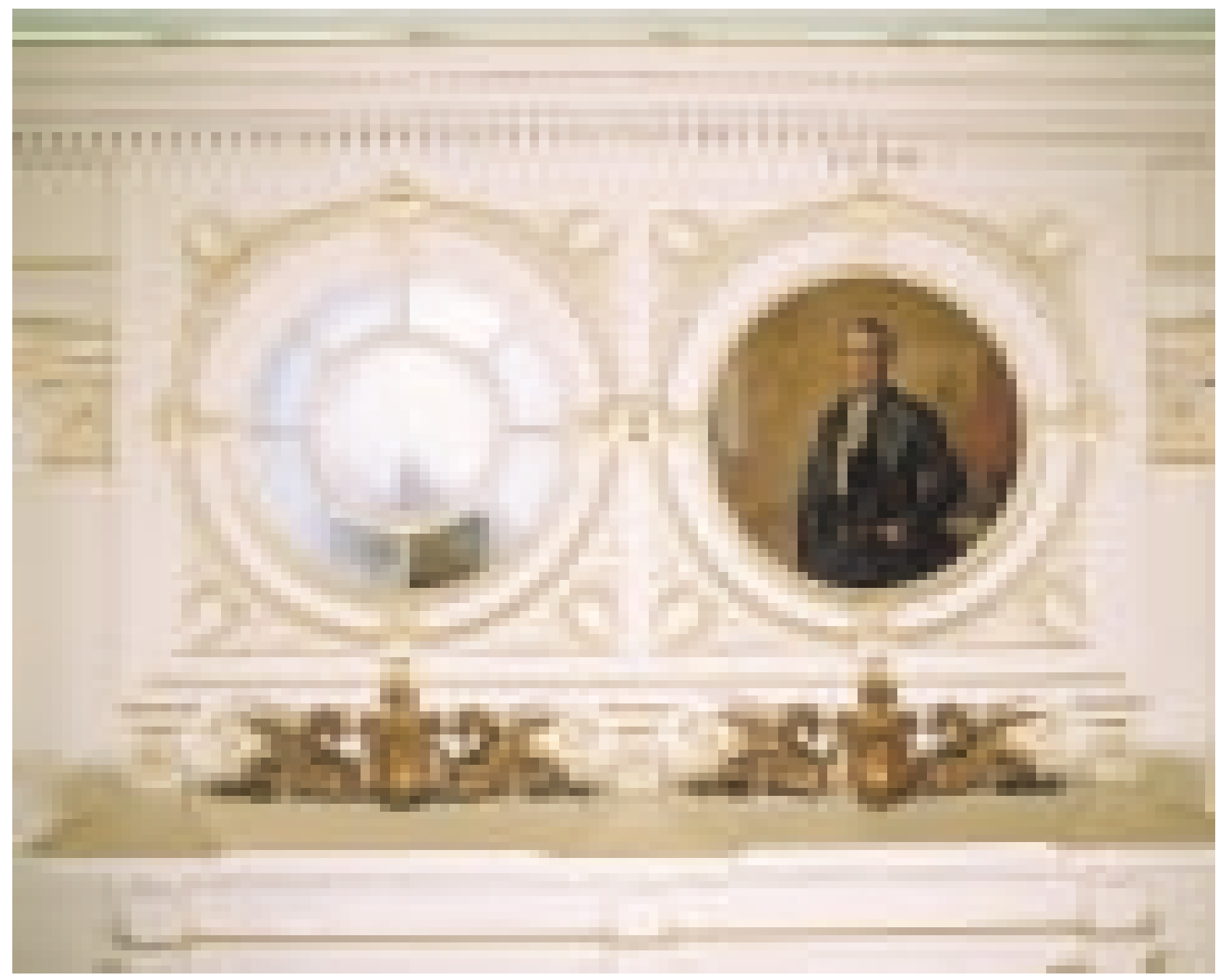

FIGURA 18 - Ledo, óleo sobre tela de Oscar Pereira da Silva - aproveitamento dos óculos para colocação dos retratos. Fotografia de José Rosael. Acervo do Museu Paulista da USP. 
20. Taunay, A.d'E. Relatório referente ao anno de $1919 \ldots$... 40

21. Taunay, Affonso d'Escragnolle. Relatório referente ao anno de 1921 apresentado, a 31 de janeiro de 1922, ao Exmo Senhor Secretario do Interior, Dr Alarico Silveira, pelo Director, em Commissão do Museu Paulista. Separata/ 149 pg.p.8. Revista do Museu Paulista, tomo XIV, 1926.

22. Sanca: parte em torno da clarabóia central do edifício do Museu Paulista.

23. Relatório referente ao anno de 1927 ... p. 18.
O episódio da Fragata União ocorreu em 8 de fevereiro de 1822, quando D. Pedro recebeu Jorge de Avilez e seu comando e intimou-os a deixar o Brasil, conduzindo as tropas portuguesas para a Europa. Taunay, ao selecionar o episódio e registrá-lo pictoricamente, acabou valorizando a permanência do príncipe.

Para Taunay, ressaltar o episódio da Sessão das Cortes, com votação do retorno do Brasil à condição de colônia, e a discussão e recusa dos representantes brasileiros em assinar o documento, foi também uma seleção de relevância, tendo em vista outros temas levantados para ser compostos.

Quanto aos custos das obras, os dados aqui apresentados são parciais, somente a tífulo de exemplificação. Taunay solicitou em 1921, para os trabalhos de preparação às comemorações do Centenário, a verba de quinhentos contos de réis, dividida em três partes: duzentos e cinqüenta contos de réis para o novo prédio; duzentos e trinta para as pinturas, esculturas, caiação e pequenos reparos do edifício e abertura de novas exposições, e vinte contos para o Jardim Botânico 20 .

As esculturas em mármore de Carrara representando Antônio Raposo Tavares e Fernão Dias Paes custaram 60 contos de réis; as seis de bronze, feitas por Nicola Rollo, Amadeo Zani e H. van Emelen, 88 contos de réis; as pinturas históricas do Salão de Honra de autoria de Oscar Pereira da Silva, em 16 contos de réis; a decoração da sanca, com 18 retratos e as datas nos quatro cantos em relevo, 50 contos de réis; os três painéis dos ciclos feitas por Henrique Bernardelli, Rodolfo Amoedo e Fernando Machado ficaram em 13 contos e 500 mil réis. Amoedo comprometeu-se em entregar mais dois painéis e Rodolfo Bernardelli a estátua de D. Pedro I, num total de 31 contos e 500 mil réis. $\bigcirc$ total das despesas foi de 259:000 $\$ 000$ para o projeto, restando 45:000\$000 para a preparação de cinco novas salas de exposição no dia do Centenário.

Em relatório de 192121, Taunay apresentou os gastos autorizados pelo governo para a preparação dos festejos do Centenário: 254 contos de réis, para encomendas de quadros, estátuas e outras aquisições diversas. A verba foi destinada especialmente para a ornamentação do Saguão, da Escadaria e do Salão de Honra. Houve um acréscimo de cinqüenta contos de réis para o projeto de decoração da Sanca da Escadaria22.

Passado o período das comemorações, tornaram-se as verbas escassas, impossibilitando aquisições ou encomendas de obras. Em 1927, Taunay solicitou a quantia de cinco contos de réis para encomendar os oito vasos ao escultor $\mathrm{De}$ Giusto. Nesse mesmo ano, era sua intenção expor a "Leitura dos Lusíadas", relato da bandeira de Antônio Pedroso de Alvarenga em 1616, e mais um outro, com tema das bandeiras, mas na dependência de verba ${ }^{23}$.

Não somente valeram a Taunay os recursos governamentais para a realização do projeto, mas também aqueles provenientes de doações de representantes da sociedade paulistana, como o Automóvel Club de São Paulo, que liberou 3.000\$000, com a intermediação de Henrique de Souza Queiroz, um dos vice-presidentes da entidade. Os membros da diretoria ofereceram quatro medalhões a óleo de autoria de Oscar Pereira da Silva, representando Antônio Carlos e Martim Francisco de Andrada e Silva, retratos que estão próximos ao 
nicho central da escadaria, Cônego Januário da Cunha Barbosa e Joaquim José da Rocha, na galeria que antecede o Salão de Honra ${ }^{24}$.

Quadro de distribuição das pinturas e esculturas na decoração

\begin{tabular}{|l|c|c|c|}
\hline \multicolumn{1}{|c|}{ Locais } & Pinturas & Esculturas & Outros \\
\hline Salão de Honra & 5 & & \\
Retratos & 2 & & \\
Cenas & 2 & & \\
Pinturas históricas & 18 & & \\
\hline Sanca & & & \\
Retratos & 6 & & \\
\hline Escadaria & 9 & & \\
Retratos & & \\
Estátuas & 7 & 16 & 4 \\
Brasões & & & \\
Ciclos & & & \\
Vasos & & & \\
Medalhões Datas & & & \\
\hline Saguão & & & \\
Retratos \\
Esculturas \\
Placas de bronze
\end{tabular}

24. Taunay, Affonso d'Escragnolle. Relatório referente ao anno de 1920 ... p. 14

\section{REFERÊNCIAS}

ABUD, Kátia Maria. O Sangue Itimorato e as nobilíssimas tradições. Tese de Doutorado apresentada ao Departamento de História da Faculdade de Filosofia, Letras e Ciências Humanas da Universidade de São Paulo. 1985. 242 f.

ALVES, Ana Maria de Alencar. O Ipiranga apropriado: ciência, política e poder: o Museu Paulista, 1893-1922. São Paulo: Humanitas/FFCLH/USP, 2001.

ARAÚJO, Karina Anhezini de. Intercâmbios intelectuais e a construção de uma História: Afonso d'Escragnolle Taunay 1911-1929. Dissertação de Mestrado em História. Faculdade de História, Direito e Serviço Social da Universidade Estadual Paulista - Campus Franca. Franca, 2003.136 f. 
BREFE, Ana Cláudia Fonseca. Um lugar de memória para a Nação. O Museu Paulista reinventado por Afonso d'Escragnolle Taunay (1917-1945). Tese de Doutorado apresentado ao Departamento de História do Instituto de Filosofia e Ciências Humanas da Universidade Estadual de Campinas. 1999. $304 \mathrm{f}$.

ELIAS, Maria José. Museu Paulista: Memória e História. Tese de Doutorado apresentada ao Departamento de História da Faculdade de Filosofia, Letras e Ciências Humana da Universidade de São Paulo. 1996. 2 vols. 1ํvol. 317 p. Anexos.

LIMA, S.F. de; CARVAlHO, V.C. de. São Paulo antiga, uma encomenda da modernidade: as fotografias de Militão nas pinturas do Museu Paulista. Anais do Museu Paulista. História e cultura Material. Nova série n. 1. São Paulo, p. 147-174, 1993.

LOPES, Maria Margaret. O Brasil descobre a pesquisa científica: os museus e as ciências naturais no século XIX. São Paulo: Hucitec, 1997.

MAKINO, Miyoko. Biografias dos pintores e catalogação das obras citadas (Exposição "São Paulo, uma encomenda da Modernidade"). Anais do Museu Paulista. História e Cultura Material. Nova série, n. 1. São Paulo, p. 175-178, 1993.

Pintura no Museu Paulista. In: OLIVEIRA, C. H. de S. (Org.). Museu Paulista: Novas Leituras. São Paulo: Museu Paulista da USP, p.38-57, 1995.

MORETTIN, Eduardo Victorio. Cinema e História: uma análise do filme "Os Bandeirantes". Dissertação de Mestrado apresentada ao Departamento de Cinema, Rádio e Televisão da Escola de Comunicações e Artes da Universidade de São Paulo. 1995. 285 f.

OLIVEIRA, Cecília Helena de Salles. O "Espetáculo do Ypiranga": Mediações entre história e memória. Tese apresentada à Divisão de Acervo e Curadoria do Museu Paulista da Universidade de São Paulo para Concurso de Livre Docência. 2000. 288 f.

OlIVEIRA FILHO, José da Costa. O edificio do Museu Paulista: um pouco da história do edifício - Monumento de Bezzi. Dissertação de Mestrado apresentada ao Departamento de História da Faculdade de Filosofia, Letras e Ciências Humanas da Universidade de São Paulo. 2000. 2 vols.

OLIVEIRA JR., Paulo Cavalcante. Affonso d'E. Taunay e a construção da memória bandeirante. Dissertação de Mestrado apresentada ao Departamento de História do Instituto de Filosofia e Ciências Sociais da Universidade Federal do Rio de Janeiro. 1994. 204 f.

WITTER, José Sebastião (dir.). Museu Paulista: Um Monumento no Ipiranga (História de um edifício centenário e de sua recuperação ). Direção-geral José Sebastião Witter; organização Heloisa Barbuy. São Paulo: Federação e Centro das Indústrias do Estado de São Paulo, 1997.

\section{FONTES DOCUMENTAIS}


Relatório especial $n^{\circ} 4$ sobre os trabalhos do ex-assistente João Alberto José Robbe, na antiga Secção de História Nacional. 1948. Datilografado. Revista do Museu Paulista, tomo X, 1918.

Relatório de 1917. Revista do Museu Paulista, tomo XI, 1919.

Relatório de 1918. Revista do Museu Paulista, tomo XII, 1920.

Relatório de 1919. Revista do Museu Paulista, tomo XIII, 1923.

Relatório de 1920. Revista do Museu Paulista, tomo XIV, 1926.

Relatórios de 1921, 1922 e 1923. Inventário Avulso de 1925, com anotações e acréscimos feitos por Afonso de Escragnolle Taunay.

Inventários de Coleções de História do Museu Paulista. Inventário de Telas - 1957.

TAUNAY, Affonso d'Escragnolle. Relatório referente ao anno de 1919 apresentado, a 28 de fevereiro de 1920, ao Excellentissimo Senhor Secretario do Interior, Doutor Oscar Rodrigues Alves, pelo Director, em Commissão, do Museu Paulista. Separata/44 p. Revista do Museu Paulista, tomo XI, 1919.

Relatório referente ao anno de 1921 apresentado, a 31 de janeiro de 1922, ao Exmo Senhor Secretario do Interior, Dr Alarico Silveira, pelo Director, em Commissão do Museu Paulista. Separata/149 p. Revista do Museu Paulista, tomo XIV, 1926.

TAUNAY, Afonso de E. Grandes Vultos da Independência Brasileira. Publicação commemorativa do Primeiro Centenário da Independência Nacional. São Paulo: Melhoramento, 1922. 229 p.

1937.

Guia da Secção Histórica do Museu Paulista. São Paulo: Imprensa Oficial do Estado,

Commemoração do Cincoentenário do Museu Paulista no Palácio do Ipiranga. São Paulo: Imprensa Oficial do Estado, 1946. 52 p.

Artigo apresentado em 11/2003. 
It deals with the presentation of fourteen Miguelzinho Dutra's water-colours unknown to the general public and the researchers. These images come to complement the image repertoire produced by the painter which are at USP's Museu Paulista.

KEYWORDS: Collection. Landscape. Painting.

Anais do Museu Paulista. São Paulo. N. Sér. v. 10/11.p.149-166 (2002-2003)

Ornamentação do Museu Paulista para o Primeiro Centenário: construção de identidade nacional na década de 1920

Miyoko Makino

Nas últimas décadas, vários estudos enfocaram o Museu Paulista, as coleções, o edifício-monumento e a gestão Afonso de Escragnole Taunay, contribuindo para o desenvolvimento do conhecimento histórico e do patrimônio arquitetônico, artístico e cultural de São Paulo. A ornamentação do Museu, organizada por Taunay, para os festejos do Primeiro Centenário da Independência, em 1922, composta essencialmente de pinturas e esculturas, visando narrar o período colonial até a Independência, é o foco deste estudo. As fontes permitem entender o caminho da seleção dos temas, a execução e a disposição das obras, em vários níveis, no Saguão, Escadaria e Salão de Honra. Os anos iniciais da gestão Taunay (1917 - 1945) foram propícios para a execução da ornamentação, visto o apoio oficial e os recursos financeiros obtidos, inclusive da sociedade paulista. A conclusão da ornamentação, no entanto, demorou duas décadas, pela exigüidade de verbas, após as festividades do Centenário. A ornamentação foi dada por concluída por Taunay, com a colocação da última ânfora na Escadaria, em 1931, e a publicação do Guia da Secção Histórica do Museu Paulista, em 1937. No entanto, as últimas pinturas foram feitas e incorporadas nos anos 60 .

PALAVRAS-CHAVE: Museu Paulista. História do Brasil. Iconografia.

Anais do Museu Paulista. São Paulo. N. Sér. v. 10/11.p.167-195 (2002-2003).

Ornamentation of Museu Paulista for the First Centennial: construction of national identity in the 1920's

Miyoko Makino

In the last decades, several studies have focused Museu Paulista, the collections, the monument building and Afonso de Escragnole Taunay's term, helping for the development of the historical knowledge and the architectural, artistic and cultural patrimony of São Paulo. The museum's ornamentation, organized by Taunay, for the commemorations of the First Centennial of Independence, in 1922, composed essentially of paintings and sculptures, aiming to narrate the colonial period up to the independence, is the focus of studies. The sources allowed us to understand the way the themes were selected, the making and the disposition of the works, in various levels, in the Hall, the Stairway and the Honour Room. The initial years of Taunay's term (1917 - 1945) were propitious for the making of the ornamentation, given the official support and the financial resources obtained, including the ones from the society of São Paulo. The finalization of the ornamentation, nevertheless, took two decades, due to the exiguity of the income, after the Centennial festivities. The ornamentation was granted as concluded by Taunay, with the placing of the last amphora on the Stairway, in 1931, and the publishing of the Guide of the Historical Section of Museu Paulista (Guia da Secção Histórica do Museu Paulista), in 1937. However, the last paintings were made and incorporated in the 1960's. KEYWORDS: Museu Paulista. History of Brasil. Iconography.

Anais do Museu Paulista. São Paulo. N. Sér.v. 10/11.p.167-195 (2002-2003).

O Sobrado da Convenção em Itu na antiga Rua do Carmo (atual Rua Barão do Itaim): uma pesquisa documental

Anicleide Zequini Rossi

O texto refere-se aos resultados de uma pesquisa documental (inventários post-morten e Livro de Notas) referente a trajetória do edifício em que está instalado o Museu Republicano na Cidade de Itu-SP, extensão do Museu Paulista-USP. Assim, a partir de todas as informações pesquisadas podemos supor que a data de construção do edifício, que abriga o Museu, seja bem anterior a 1850, ano que the tem sido apontado em diversos texto. Este ano registra sim, a presença de uma das famílias moradoras daquele edifício: os Almeida Prado que receberam os Convencionais de 1873.

PALAVRAS-CHAVE: Museu Republicano Convenção de Itu- MP/USP. Itu, História. Itu, Museu.Almeida Prado, Família. 